\title{
The Evolution of the Nexus
}

\author{
The Quest for Balance
}

On March 15, 1999, Sir Leon Brittan, then Vice President of the European Commission, addressed his audience at the World Trade Organization (WTO) High Level Symposium on Trade and Environment by emphasizing the "need to reconcile the competing demands of economic growth, environmental protection and social development." He then added that "[p]ursuing any one of these three at the expense of the other two [would] inevitably lead to an unbalanced approach."1 Indeed, Sir Brittan had been one of the most vocal advocates of the importance of pushing the trade and environment debate forward and, just one year prior, had come up with the idea for the symposium as a perfect way to bring together top-level policymakers in both fields. The ideas exposed in his speech - the acknowledgment that both trade and environmental law pursue valuable goals and the need to pursue such goals in a mutually supportive manner-were not new. If anything, his words reflected a sentiment that had been floating around for more than a decade and that found its roots in the report prepared in 1987 by the Brundtland Commission, Our Common Future. ${ }^{2}$ The Brundtland Report, as it is commonly known, introduced the world to the notion of 'sustainable development', which was intended to serve as a frame of reference to avoid or minimize frictions between the two regimes, and as a common language, able of being understood by both free traders and environmentalists. ${ }^{3}$

The 'dialogue of the deaf' that had characterized the previous decades suddenly seemed to be over, as both communities acknowledged the need to balance free trade and environmental protection as two sometimes conflicting, yet complementary, values. Accordingly, the trade regime began increasing the space provided to allow countries to protect the environment, while the international environmental regime came to terms with the idea of balancing the

1 Sir Leon Brittan QC, Address at the wTO High Level Symposium on Trade and the Environment, Geneva, Mar. 15, 1999.

2 World Commission on Environment and Development, Our Common Future (Oxford University Press, 1987) [hereinafter Brundtland Report], Ch. 3, para. 2.4.

3 David Runnalls and Aaron Cosbey, 'Trade and Sustainable Development. A Survey of the Issues and A New Research Agenda' (1002) IISD Report, 12, 13. 
environmental component of sustainable development with economic growth and social inclusion.

One scholar has described this as a "new era in the trade-environment debate," beginning in the mid-199os, and fostered not only by the increasing attention given to the environment by trade negotiators, but also by an "enlightened" Appellate Body jurisprudence. ${ }^{4}$ This "new era" was characterized by countless efforts to avoid or reduce potential and existing conflicts between trade and environmental rules, the core question being how to ensure that trade rules are not used to override environmental regulations, without, at the same time, allowing protectionist measures disguised as environmental policies. The "new era", while embodying a certain evolution of the nexus, has not however proceeded at the same pace at all levels. Within the newly established WTO, the larger and more diverse membership, as well as the increasing power of less developed countries within the Organization, allowed this evolution to proceed at a slower pace, largely limited to the 'enlightened' jurisprudence of the Appellate Body, which has been giving increasing weight to the environmental side of the equation when interpreting Wто provisions. On the other hand, the efforts of many industrialized countries, such as the United States (US) or the countries of the European Union (EU), were not similarly constrained, and it is in bilateral and regional contexts that negotiators have worked towards reducing potential conflicts by introducing environmental language directly in the text of trade agreements.

This is an evolution à la carte, as one could define it, and, more importantly, an evolution which, despite all the steps forward, keeps unfolding against the same backdrop we saw in the previous chapter: international trade law continues to provide the framework of reference and to represent the 'official language' of the debate, which ultimately boils down to whether the existing trade norms are adequate to strike a balance between trade liberalization and environmental protection. It should be no surprise then that even when more space is given to environmental values, "that space is always designed as exceptional. And the [neoliberal] narrative guarantees that such exceptions are seen with a skeptical eye." 5

4 Steve Charnovitz, 'The WTO's Environmental Progress' (2007) 10(3) Journal of International Economic Law 685, 686.

5 Harlan Grant Cohen, 'What is International Trade Law For?' (2019) 113(2) American Journal of International Law 326, 331. 
[A] bad [trade] agreement is likely to be defined in Congress and the media as any agreement that doesn't have labor and environment in it. ${ }^{6}$

US Ambassador ROBERT ZOELLICK, 1999

On October 4, 1992, Clinton gave a major speech on the North American Free Trade Agreement (NAFTA) at North Carolina State University where, while expressing his general support for the agreement, he also recognized its deficiencies. ${ }^{7}$ In particular, he expressed concerns regarding environmental protection, labor relations, and safeguarding against import surges. Clinton's position was straightforward:he would not sign legislation implementing NAFTA until new "supplemental agreements" had been negotiated with Mexico and Canada regarding these issues. ${ }^{8}$

Candidate Clinton's speech reflected a change of perspective compared to the previous decades. In 1971, the Group on Environmental Measures and International Trade (EMIT Group) had prepared a document describing the negative impacts of pollution control measures on international trade flows, translating the dominant narrative of the time. Clinton's request for the supplemental environmental agreement conveyed two complementary new ideas: first, that the rapid expansion of trade could pose serious problems for the environment, ${ }^{9}$ and second, that this undesirable outcome should be

6 Ambassador Robert Zoellick, US Trade Representative, quoted in Morton K. Kondracke, Battles in Seattle Make Free Trade an Election Issue, Roll. Call. (Dec. 9, 1999), 1999 WL 14666783 .

$7 \quad$ Bill Clinton, 'Expanding Trade and Creating American Jobs', at North Carolina State University (Oct. 4, 1992) in (1993) 23 Environmental Law 683. See Candidate Bill Clinton's Proposal for Supplemental Agreements on NAFTA, in Rodney Dabell and Michael Henfeld (eds.), Beyond NAFTA, The Western Hemisphere 192 (Oolichan Books,1993).

8 See Steve Charnovitz, 'The NAFTA Environmental Side Agreement: Implications for Environmental Cooperation, Trade Policy, and American Treatymaking' (1994) 8 Temple International \& Comparative Law Journal 257; Robert Housman, 'The North American Free Trade Agreement's Lessons for Reconciling Trade and the Environment' (1994) 30 Stanford Journal of International Law 379, 382.

$9 \quad$ David Runnalls, 'Trade Liberalization and Sustainable Development', Papers presented at the GATT Symposium on Trade, Environment and Sustainable Development, July 28, 1994, 19. Many of the papers presented at the GATT Symposium on Trade, Environment and Sustainable Development were prepared by environmental experts and they showed an environmental perspective of the trade/environment nexus. Jeffrey McNeely, of the International Union for the Conservation of Nature (IUCN), for example, argued that "the GATT Agreement ... has significant negative implications for biodiversity and could itself undermine the work initiated by the Earth Summit," stressing that IUCN shares the Rio Conference's concern for the lack of attention given to the environmental implication of international trade. Jeffrey A. McNeely, 'Trade and Biological Diversity: The 
avoided at all costs. In other words, it conveyed the message that economic growth had to be sustainable.

The notion that growth and development ought to be sustainable, made 'popular' by the Brundtland Report, had its origin more than a decade prior, and more precisely in the thought and work of one of the greatest internationalists of the twentieth century, whose role behind the scenes at the Stockholm Conference is just one of her many contributions to modern society: Barbara "Lady Jackson" Ward. ${ }^{10}$

\subsection{LadyJackson}

Barbara Ward, also known as "Lady Jackson" after her marriage to Sir Robert Jackson, was born on May 23, 1914 in York, England. Since her early school years, she proved to be a very serious student, and certainly a gifted one, showing great promise, which took her all the way to Oxford. There, she chose to enroll in the newly started School of Philosophy, Politics, and Economics, the very same School that James Meade had attended only a few years before.

It was at Oxford that she began her social activism, which she would carry on for her whole life. ${ }^{11}$ In this, she was surely influenced by her father, who "was a man of very liberal opinions and brought [her] up as a Social Democrat" from a very early age. ${ }^{12}$ During her college years, she was deeply affected by the massive unemployment of the 1930s, and since her very first book, which she published when she was only 24 years old, she became one of the most articulate and persuasive champions of the poor, making a compelling case for the rich to be more responsive to their needs. ${ }^{13}$

Her interest for the environment came later, during the 196os, and found its first and most powerful expression in the Pegram Lectures she delivered at Columbia University, which were later published as Spaceship Earth in 1966.

Internalization of Environmental Costs', Papers presented at the GATT Symposium on Trade, Environment and Sustainable Development, July 28, 1994, 49, 51-2.

10 For a survey of different opinions regarding the origin of the term 'sustainable development', see Claire Brighton, 'Unlikely Bedfellows: The Evolution of the Relationship Between Environmental Protection and Development' (2017) 66 International \& Comparative Law Quarterly 209, 222.

11 Jean Gartlan, Barbara Ward: Her Life and Letters (A\&C Black, 2010), p. 3.

12 Interview with Mary Evelyn Jegen, SND, Rome, Sept. 17, 1973, as quoted in Gartlan, Barbara Ward (n 11) 3 .

13 The book in question is The International Share-Out, published in 1938 and addressing the international tensions created among colonialist nations. Maurice Strong, 'Transcending Divisions: Work for the Stockholm Conference', in David Satterthwaite, Barbara Ward and the Origins of Sustainable Development (International Institute for Environment and Development, 2006), p. 14. 
In this seminal book, she vocally argued that "our planet is not much more than the capsule within which we have to live as human beings ... We depend upon a little envelope of soil and a rather larger envelope of atmosphere for life itself. And both can be contaminated and destroyed."14 Ten years later, she demanded from governments and international agencies a higher priority on meeting basic needs for water, sanitation, health and education in both rural and urban areas, and even set out the costs of doing so, thus anticipating the Millennium Development Goals (MDG s) by roughly 30 years. ${ }^{15}$

It was precisely because of her ability to think in terms of both environment and development, that Maurice Strong asked her to co-author with Renè Dubos Only One Earth, the volume that served as the scientific basis and conceptual framework for the Stockholm Conference: Strong knew from the very start that Barbara Ward would bring her concern for 'our fragile planet' and, at the same time, would never write a book that did not have poverty reduction and social justice at its core. ${ }^{16}$ Her efforts and her vision were necessary to mediate between the diverging approaches and interests of Northern and Southern environmentalists, where the former "have typically adopted a technocratic approach to environmental protection, emphasizing global management of the environment based on scientific principles," neglecting the struggle for social and economic justice which characterized Southern environmentalism. ${ }^{17}$

As a result, Only One Earth can be seen as the first book on sustainable development, making it the task of the Stockholm Conference to "define what should be done to maintain the Earth as a place suitable for human life not only now, but also for future generations." ${ }^{18}$ The term 'sustainable development' was then used in a report published by the International Institute for Environment and Development, titled Banking on the Biosphere, in 1979, when Barbara Ward was Director of the Institute. One year later, in the 1980 World Conservation Strategy, the notion of sustainable development replaced that of ecodevelopment as the guiding principle. ${ }^{19}$

\footnotetext{
14 Barbara Ward, Spaceship Earth (Columbia University Press, 1966), p. 15.

15 Satterthwaite, Barbara Ward (n 13$) 8$.

16 Ibid., p. 11.

17 Carmen G. Gonzalez, 'Beyond Eco-Imperialism: An Environmental Justice Critique of Free Trade' (2001) 78(4) Denver University Law Review 981, 985-6.

18 Barbara Ward and René Dubos, Only One Earth (W.W. Norton \& Company, 1972), p. 25.

19 Satterthwaite, Barbara Ward (n 13) 10. See Robert E. Stein and Brian D. G. Johnson, Banking on the Biosphere (Aero Publishing Ltd, 1979) and IUCN, UNEP, WWF, FAO, UNEsco World Conservation Strategy: Living Resource Conservation for Sustainable Development (1980).
} 


\subsection{Same Game, New Rules}

The notion of sustainable development represented the cornerstone of the discussions that allowed an ad-hoc commission to prepare a second international environmental conference to be held in Rio de Janeiro in 1992. To head the commission, the United Nations (UN) Secretary General deliberately chose a political leader who had become Norway's Prime Minister after serving as the country's Minister of the Environment for several years (1974-79). The political leader in question was yet another woman who, just like Barbara Ward, understood the widespread feeling of frustration around the treatment of developing countries' concerns in Stockholm, while making sure that, at the same time, the environment would remain a central issue in both national and international decision-making. ${ }^{20}$ The political leader in question was the woman who has traditionally been associated with the notion of sustainable development, Norway's Prime Minister at the time, Gro Harlem Brundtland.

Drawing on the past intellectual concepts of 'Spaceship Earth' and 'sustainable development', the report produced by the Brundtland Commission managed, for the very first time, to integrate economics with environmental protection, by showing "what conservation might mean for economic policy, [and] how misguided economic policy could degrade the environment." ${ }^{21} \mathrm{By}$ doing so, the introduction of this new overarching principle changed the rules of the game for both the trade and environmental regimes.

As to the former, this principle shifted the focus away from economic growth plain and simple. The term development reflects "some set of desirable goals or objectives for society"22 which undoubtedly include but are not limited to economic growth -intended as a rising level of income per capita. It refers to a process of transformation which combines economic growth with broader social and cultural changes, to enable individuals to achieve a certain 'quality of life' and realize their full potential. ${ }^{23}$ At the same time, "the dimension of sustainability brings the recognition that [growth and] development must ... adhere to the physical constraints imposed by ecosystems, so that environmental considerations have to be embedded in all sectors and policy areas."24

As a result, while the preamble to the General Agreement on Tariffs and Trade (GATT) identified as the core objective of the Agreement-and of the

\footnotetext{
$20 \quad$ Brundtland Report, pp. xi-x.

21 David Pearce et al., Blueprint For A Green Economy (Earthscan, 1990), p. xii.

22 Ibid., p. 1.

23 Neil Carter, The Politics of the Environment: Ideas, Activism, Policy (Cambridge University Press, 2018), p. 211.

24

Ibid., p. 212.
} 
multilateral trading system at the time-raising standards of living, ensuring full employment and a large and steadily growing volume of real income and effective demand, the wTO, influenced by the Report and the emergence of this new paradigm, was asked to pursue the much broader objective of sustainable development, seeking both to protect and preserve the environment while doing so. Thus, the growth and development promoted by the trade regime would have to be sustainable, and trade rules themselves should not undermine domestic and international efforts towards securing the environmental pillar of sustainable development.

But the rules have not changed just for free traders. Environmentalists too found themselves facing a new reality. In Stockholm, the environment was the undeniable and unrivaled star. The emergence of sustainable development "shifted the debate from traditional environmentalism with its primary focus on environmental protection, to the notion of sustainability, which requires a much more complex process of trading off social, economic, and environmental priorities."25 Many developing countries had expressed their concern, during the Stockholm Conference-and in particular in the meeting in Founex a few weeks before - that there was a risk that environmental protection measures could be used by industrialized powers to impose environmental conditionality on their development. Twenty years later, these concerns were finally addressed and the Brundtland definition of sustainable development was "as much concerned with economic and social development as it [was] with environmental protection. ${ }^{26}$

\subsection{Which Takes Precedence, Environment or Development?}

On April 2, 1992, Tommy Koh heaved a sigh of relief as he left a small boardroom on the 29th floor of the UN building in New York. Just a few days prior, acting as Chairman of the Preparatory Committee of the Rio Conference, Koh had gathered a small group of representative countries-seven industrialized and seven developing countries-to finalize the draft of what eventually became the Rio Declaration on Environment and Development. ${ }^{27}$ The Preparatory Committee had met four times over the two years leading up to Rio, but it was not until the fourth meeting that the drafting of the Declaration had actually begun. Over those two years, various proposed drafts had been

25 Ibid., p. 215 .

26 Ibid., p. 211.

27 See Howard Mann, 'The Rio Declaration' (1992) 86 Proceedings of the American Society of International Law 405, 408, and Jeffrey D. Kovar, 'A Short Guide to the Rio Declaration' (1993) 4 Colorado Journal of International Environmental Law \& Policy 119, 122. 
tabled, revealing the predictable North-South divide. ${ }^{28}$ It was only during the very last days that Koh was able to mediate between the two different positions and to negotiate the final compromise.

Although often defined as a balanced compromise between developmental and environmental goals, the final text of the Declaration largely reflected the negotiating text presented by the Group of 77 developing countries ( $\left.G_{77}\right)$. Twenty years earlier, in Founex, the differences between industrialized and developing countries over a number of issues - who was the cause of environmental damage and who would have to pay for it-had emerged as clear as day. In Founex, developing countries did not find themselves sufficiently prepared, and they wanted to avoid committing the same mistake in Rio at all costs. To this end, despite there being differences between the African, Latin American, and Asian segments of the $\mathrm{G}_{77}$, the Group was able to develop a common negotiating strategy, largely as a result of the efforts of the South Center. ${ }^{29}$

The main point of contention between the North and the South, both in Stockholm and in Rio, was whether the emphasis should be on the environment or development. According to industrialized countries, the environment should be the focus of the Conference, while developing countries argued the Conference should be aimed at establishing their right to development. ${ }^{30}$ The title of the Rio Declaration itself reflects, at least to a certain extent, the South's position: the original title - "Earth Charter" — had been forcefully contested by the G77 and China, as it seemed to suggest an 'undue' emphasis on the environment at the expense of development, and the final title- "On Environment and Development" - while clearly linking the two, did not emphasize the former over the latter, shattering industrialized nations' dream to produce a document focused solely on solving global environmental problems. ${ }^{31}$

28 Proposed drafts include those presented by Argentina, Australia, Canada, the European Community, Japan, the United States, a group of Nordic countries, the Group of 77 developing countries and China, the United Kingdom and Denmark (on behalf of several nongovernmental organizations), and Russia.

29 See Report of the South Center on Environment and Development, Towards a Common Strategy for the South in the UNCED Negotiations and Beyond (South Center, 1991).

30 See e.g. M.P.A. Kindall, 'Talking Past Each Other at The Summit' (1993) 4 Colorado Journal of International Environmental Law \& Policy 69, 71-2; Mann, 'The Rio Declaration' (n 27) 409; Ved P. Nanda, 'Sustainable Development, International Trade and the Doha Agenda for Development' (2005) 8 Chapman Law Review 53, 56; and Chris K. Mensah, 'The Role of Developing Countries', in Luigi Campiglio et al. (eds.), The Environment After Rio: International Law and Economics (Springer, 1994), p. 36.

31 Kovar, 'A Short Guide to the Rio Declaration' (n 27) 123, and Nanda, 'Sustainable Development' (n 30) 56-7. 
While the title of the Declaration can be seen as ruling out the superiority of environmental concerns over developmental ones without offering, however, a conclusive answer to the old question - "which takes precedence, environment or development?"-, the final text of Principle 3 seems to clear up any confusion on the matter. The Principle, opposed by most industrialized countries, especially the US, and insisted upon by developing ones, explicitly acknowledges the existence of a 'right to development' which "must be fulfilled so as to equitably meet developmental and environmental needs of present and future generations." ${ }^{32}$ On the other hand, the Declaration failed to recognize a 'right to a healthy environment', as proposed by the North, and opted instead for the reference to a mere 'entitlement' to a "healthy and productive life in harmony with nature."33

The developing countries' insistence on the recognition of a right to development, as well as their broader approach to the Rio negotiations, were fueled by their deep-seated fear that an excessive focus on the environment could be used as a tool to hold back their development opportunities. After all, 20 years had passed but these countries still regarded many environmental measures, in particular when related to trade, as possibly disguising protectionist intents. It was therefore necessary, in their view, to ensure that trade and environment issues would not move forward in isolation from wider development commitments. ${ }^{34}$ To this end, a group of Latin American countries, led by Mexico, insisted upon the inclusion of a Principle that would clarify the relationship between trade and the environment, while safeguarding them against trade

32 United Nations Conference on Environment and Development, Rio de Janeiro, Brazil, June 3-14, 1992, Rio Declaration on Environment and Development, U.N. Doc. A/CONF.151/ 26/Rev.1 (Vol. I), Annex I (Aug. 12, 1992) [hereinafter Rio Declaration], Principle 3.

33 Ibid., Principle 1. The need for a recognition of a human right to a healthy environment among existing human rights is still debated today. See e.g. John H. Knox and Ramin Pejan (eds.), The Human Right to a Healthy Environment (Cambridge University Press, 2018); Philippe Cullet, 'Definition of an Environmental Right in a Human Rights Context' (1995) 13 Netherlands Quarterly of Human Rights 25; James T. McClymonds, 'Human Right to a Healthy Environment: An International Legal Perspective' (1992) 37 New York Law School Law Review 583; John Lee, 'The Underlying Legal Theory to Support a Well-Defined Human Right to a Healthy Environment as a Principle of Customary International Law' (200o) 25 Columbia Journal of Environmental Law 283 (2000); Marc Paellemarts, 'The Human Right to a Healthy Environment as a Substantive Right', in Maguelonne DejeantPons and Marc Paellemarts (eds.), Human Rights and the Environment (Council of Europe, 2002); Rebecca Bratspies, 'Do We Need a Human Right to a Healthy Environment?' (2015) 13(1) Santa Clara Journal of International Law 31.

34 Scott Vaughan, 'Trade and Environment: Some North-South Considerations' (1994) 27 Cornell International Law Journal 591, 591-2. 
measures adopted to influence their environmental practices. ${ }^{35}$ Principle 12 was added to the Declaration as a result:

States should cooperate to promote a supportive and open international economic system that would lead to economic growth and sustainable development in all countries, to better address the problems of environmental degradation. Trade policy measures for environmental purposes should not constitute a means of arbitrary or unjustifiable discrimination or a disguised restriction on international trade. Unilateral actions to deal with environmental challenges outside the jurisdiction of the importing country should be avoided. Environmental measures addressing transboundary or global environmental problems should, as far as possible, be based on an international consensus. ${ }^{36}$

The goal of this principle was to prevent industrialized countries from unilaterally imposing trade sanctions against developing countries under the guise of enforcing environmental norms. This language, which has no analogue in the Stockholm documents, recalls the chapeau of GATT Article Xx to the letter, where it requires trade measures adopted for environmental purposes to "not constitute a means of arbitrary or unjustifiable discrimination or a disguised restriction on international trade", while the third and fourth sentences clearly codify the wellknown holding of the GATT panel in the Tuna/Dolphin case. ${ }^{37}$

\subsection{Trade Too Can Harm the Environment}

With the development agenda gaining considerable ground both in environmental and trade fora, and with the principle of sustainable development as the overarching principle guiding future negotiations, ${ }^{38}$ the rules of the

35 Mensah, 'The Role of Developing Countries' (n 30) 46; and Kovar, 'A Short Guide to the Rio Declaration' (n 27) 132.

$36 \quad$ Rio Declaration, Principle 12.

37 Report of the GATT Panel, United States - Restrictions on Imports of Tuna, DS21/R-39S/155 (Sept. 3, 1991) (not adopted) [hereinafter US —Tuna I], para. 5.27. See David A. Wirth, 'The Rio Declaration on Environment and Development: Two Steps Forward and One Back, or Vice Versa?' (1995) 29 Georgia Law Review 599, 641.

38 Many mEAs contain a caveat such as the one we can find in the chapeau of GatT Article xx. See e.g. Article 3.5 of the United Nations Framework Convention on Climate Change (UNFCCC), Article 3.5. Climate change negotiations represent a particularly fitting example, as trade measures are nearly never discussed as a tool to contribute to climate change mitigation, but rather as a threat to economic development in developing and least-developed countries. The creation of the Forum on the Impact of Implementation of Response Measures in 2011, was aimed precisely as addressing the negative impact that 
game for environmentalists had decisively changed, making development an essential component of the evolution of the trade/environment nexus going forward. At the same time, the situation had drastically changed for free traders. In particular, the dimension of sustainability brought the recognition that economic growth could no longer be pursued decoupled from environmental considerations, which instead needed to be effectively embedded in all sectors and policy areas. ${ }^{39}$

The consequences of this paradigm shift for the interplay between the two regimes should not be underestimated. For nearly 20 years, the relationship between trade and the environment had been framed in a very one-sided fashion, which may be summed up in the following question: "to what extent may environmental measures act as deterrents to freer trade and how should such deterrents be dealt with?"40 In other words, the trade community regarded measures adopted for environmental purposes as a potential obstacle to trade liberalization, while the other side of the question - whether liberalized trade could harm the environment-was not even taken into consideration. As convincingly explained by Bhagwati in a piece aptly titled The Case for Free Trade, economic growth "enables governments to tax and to raise resources for a variety of objectives, including environmental protection ... freer trade enables pollution-fighting technologies available elsewhere to be imported ... [and] can also lead to better environmental outcomes from a shift in the composition of production."41 The very same arguments were advanced by global economic institutions, such as the World Bank, who published a report contending that "[1]iberalized trade fosters greater efficiency and higher productivity and may actually reduce pollution by encouraging the growth of less polluting industries and the adoption and diffusion of cleaner technologies." ${ }^{2}$

Overall, these arguments reflected the neoliberal view of "environmental protection through economic means," 43 which was backed up by a model known as the Environmental Kuznets Curve (EKC), and which supported the hypothesis that during the very first stages of social and economic advancement, there will necessarily be environmental degradation and harm, while

mitigation measures adopted by industrialized countries risk having on the economies of less developed ones.

39 Carter, The Politics of the Environment (n 23) 212.

40 J. Owen Saunders, 'Trade and Environment: The Fine Line Between Environmental Protection and Environmental Protectionism' (1992) 47(4) International Journal 723, 726.

41 Jagdish Bhagwati, 'The Case for Free Trade' (1993) Scientific American 43.

42 World Bank, World Development Report (Oxford University Press, 1992), p. 67.

43 James K.R. Watson, The WTO and the Environment (Routledge, 2013), p. 101. 
once a country has reached a higher level, "there will be money and assets free to invest in environmental goods such as pollution control and waste management." 44 As a result, the alarming fears of environmentalists that free trade increases economic growth, which in turn harms the environment, were considered misplaced and rapidly dismissed. ${ }^{45}$

The paradigm shift introduced with the notion of sustainable development, on the other hand, began to quietly shake the confidence of free trade supporters over the entirely beneficial impact of trade liberalization on the environment. Suddenly, the focus was no longer solely on the potential negative impact that environmental measures could have on international trade flows, but equally on the harm that liberalized trade could cause to the environment. Slowly, the trade community itself began to realize that trade could harm the environment in various ways - and not just in low-income countries-and it was therefore necessary to eliminate or reduce this harm to a minimum. And this is precisely when environmental safeguards made their first appearance within the text of trade agreements.

\subsection{Assessing Environmental Impacts}

On November 16, 1999, just a few weeks before the opening of the Wто Ministerial Conference in Seattle, President Clinton issued Executive Order 13,141, committing the US government to conduct environmental reviews of trade agreements for the very first time. ${ }^{46}$ It is no coincidence that the Order was issued the same day as the administration's Declaration on Environmental Trade Policy, which pledged to "[take] fully into account environmental implications throughout the course of the negotiations, including by performing a written environmental review." 47 Accordingly, the Order committed the US government to "factor environmental considerations into the development of its trade negotiating objectives [through] a process of ongoing assessment and evaluation, and, in certain instances, written environmental reviews."48

The Order concluded almost a decade of judicial battles, which found their fountainhead in a provision of the National Environmental Protection

44 Ibid., quoting World Bank, World Development Report (n 42).

45 Bhagwati, 'The Case for Free Trade' (n 41) 43; Gene M. Grossman and Alan B. Krueger, 'Economic Growth and the Environment', N BE R Working Paper Series, Working Paper No. 4634 (Feb. 1994).

46 Exec. Order No. 13,141, 64 Fed. Reg. 63,169 (Nov. 16, 1999).

47 White House Policy Declaration on Environment and Trade (Nov. 16, 1999). See James Salzman, 'Seattle's Legal Legacy and Environmental Review of Trade Agreements' (2001) 31(3) Environmental Law 501, 503.

Exec. Order No. 13,141, §1. 
Act (NEPA), requiring US federal agencies to prepare Environmental Impact Assessments (EIAs) for proposed major federal actions that may significantly affect the quality of the human environment. ${ }^{49}$ Since NEPA's adoption, environmental reviews have become a cornerstone of environmental law, being introduced in the domestic legislation of many other states, ${ }^{50}$ as well as in international legal instruments. ${ }^{51}$

When NAFTA was being negotiated, the real question became whether NEPA applied to trade agreements. Convinced that it did and wanting the Office of the United States Trade Representative (USTR) to conduct an assessment of NAFTA, Public Citizen, Sierra Club, and Friends of the Earth filed a suit in US district court to decide on this matter. ${ }^{52}$ The suit led to the dispositive case Public Citizen v. Office of the U.S. Trade Representative, ${ }^{53}$ which ruled against the necessity of EIA s for trade agreements, ${ }^{54}$ only to be voided a few years later by Clinton's Executive Order, which made such reviews mandatory.

49 NEPA uses the expression 'Environmental Impact Statements' or EIs. According to paragraph 4332, "all agencies of the Federal Government shall include in every recommendation or report on proposals for legislation and other major Federal actions significantly affecting the quality of the human environment, a detailed statement by the responsible official on (i) the environmental impact of the proposed action, (ii) any adverse environmental effects which cannot be avoided should the proposal be implemented, (iii) alternatives to the proposed action, (iv) the relationship between local short-term uses of man's environment and the maintenance and enhancement of long-term productivity, and (v) any irreversible and irretrievable commitments of resources which would be involved in the proposed action should it be implemented." 42 U.s.c. $§ 4332$ (1988).

50 Kevin Gray, 'International Environmental Impact Assessment' (2000) 11 Colorado Journal of International Environmental Law \& Policy 83, 89.

51 Principle 17 of the Rio Declaration, for instance, provides that "Environmental impact assessment, as a national instrument, shall be undertaken for proposed activities that are likely to have a significant adverse impact on the environment and are subject to a decision of a competent national authority." Rio Declaration, Principle 17. Other international legal instruments providing for EIAs include the Espoo Convention, the Convention on Biological Diversity (СвD), the United Nations Convention on the Law of the Sea (UNCLOS), and the World Charter for Nature. See Convention on Environmental Impact Assessment in a Transboundary Context, Feb. 25, 1991, 1989 U.N.T.S. 309, Convention on Biological Diversity, June 5, 1992, 1760 U.N.T.S. 79, United Nations Convention on the Law of the Sea, Dec. 10, 1982, 1833 U.N.T.S. 397, and United Nations General Assembly Resolution, World Charter for Nature, A/REs/37/7 (Oct. 28, 1982).

52 See Steve Charnovitz, 'No Time for NEPA: Trade Agreements on a Fast Track' (1994) 3 Minnesota Journal of Global Trade 195, 208; and Salzman, 'Seattle's Legal Legacy' (n 47) 508.

53 Public Citizen v. Office of the US Trade Representative, 782 F. Supp. 139, 141 (D.D.C. 1992).

54 While initially dismissed for lack of standing and lack of final agency, the case was refiled and the district court granted a summary judgment and ordered the USTR to prepare an environmental impact assessment of NAFTA. However, the D.C. Circuit reversed the 
Even before Clinton's Order, the idea that trade expansion-just as the norms that facilitate it — could be harmful for the environment had started to gain traction. As a result, while the case was still pending in court, although not required to do so by law, the USTR did convene an interagency task force with the specific job of examining the environmental issues most likely to arise during the negotiation and drafting of NAFTA, and this 'informal' review, as USTR officials were calling it, ${ }^{55}$ ultimately had a quite significant impact on the final text of the agreement. One of the main findings of the review was the potential race-to-the-bottom consequences of the agreement, and NAFTA Article $1114,{ }^{56}$ as well as several provisions of its environmental side agreement (North American Agreement on Environmental Cooperation or NAAEC), ${ }^{57}$ were drafted precisely to address these concerns, ensuring that the parties maintained their environmental, health, and safety standards. The review similarly called for assurances that NAFTA would not undermine the parties' obligations under certain environmental agreements, hence Article 104 of NAFTA, which clarifies the relationship between these treaties and NAFTA itself. ${ }^{58}$

Following the NAFTA review and Clinton's Executive Order, the Office of the USTR issued an environmental review of the Uruguay Round, right after the EU had launched its Sustainability Impact Assessment of the Proposed New Round of Multilateral Trade Liberalization. ${ }^{59}$ These initiatives were perfectly in line with the position taken by many international organizations during the very same years. The Commission on Sustainable Development (CSD), created during the Rio Conference, for instance, encouraged "Governments to develop or strengthen processes to assess the environmental effects of trade policies ... and promote transparency and openness to the public in these processes." ${ }^{\prime 6}$

lower court decision on purely administrative law grounds. See Charnovitz, 'No Time for NEPA' (n 52) and Salzman, 'Seattle's Legal Legacy' (n 47).

55 Salzman, 'Seattle's Legal Legacy' (n 47) 508.

56 See later in the text.

57 North American Agreement on Environmental Cooperation, US-Can.-Mex. 32 I.L.M. 1482 (1993) [hereinafter NAAEC].

$5^{8}$ Another important finding of the review was the environmental degradation caused by maquiladoras along the US-Mexico Border, which led to the adoption of the Integrated Border Environmental Plan.

59 This initiative built on the 1992 EIA of the Common Market. See Salzman, 'Seattle's Legal Legacy (n 47) 512 .

60 U.N. ESCOR, Comm'n on Sustainable Dev., 3rd Sess., Supp. No. 12 §69, U.N. Doc. E/CN/ $.17 / 1995 / 36$ (1995). A more recent report in April 2000, similarly called for assessments that can "anticipate potentially adverse scale effects of trade liberalization and, where possible, to avoid or mitigate such effects through appropriate environmental policies." See Salzman, 'Seattle's Legal Legacy' (n 47) 511. 
Along the very same lines, the Organization for Economic Cooperation and Development (OECD), the United Nations Environment Program (UNEP), and the United Nations Conference on Trade and Development (UNCTAD) began sponsoring projects and developing guidelines for conducting environmental reviews. ${ }^{61}$ The importance of conducting EIA s of trade negotiations was also raised at the wTo. During several meetings of the Committee on Trade and Environment (СтE), the representative of the United States emphasized the importance of environmental reviews to develop the necessary information to ensure "the goal of trade liberalization in conjunction with an overall commitment to sustainable development." 62 Along the same lines, the Canadian representative listed the benefits of identifying and discussing the environmental consequences of trade liberalization in relation to specific WTO negotiations: it would help, among other things, "to identify potential problem areas and the positive effects of trade liberalization early in the process ... identify ways to mitigate environmental effects and inform decision-makers." ${ }^{\prime 3}$ These persistent suggestions, however, have gone nowhere and the WTO managed to remain immune to the spreading 'environmental reviews' enthusiasm. ${ }^{64}$

As a result, a number of countries, including the US, the EU, and Canada, have been introducing provisions requiring parties to conduct environmental impact assessments of trade agreements in their bilateral and regional trade negotiations, ${ }^{65}$ starting with the NAFTA environmental side agreement, which includes EIAs in the list of the parties' General Commitments, ${ }^{66}$ up until one of the more recent agreements signed by the EU with Japan, where the parties have committed to monitor, assess, and review the environmental impact of the implementation of the agreement. ${ }^{67}$

Conducting such reviews can indeed prove beneficial for the parties' environments, as they help negotiators identify those aspects of the agreements that are more likely to have a negative environmental impact. This might in turn lead to the introduction of environmental safeguards within the text, just

61 See e.g. OECD, Methodologies for Environmental and Trade Reviews 5, OECD Doc. OECD/ GD(94)103 (1994); and OECD, Assessing the Environmental Effects of Trade Liberalization Agreements: Methodologies (2000).

62 WT/CTE/M/22 (Oct. 29, 1999), para. 8.

63 Ibid., para. 10.

64 Ibid., para. 9. See Salzman, 'Seattle's Legal Legacy' (n 47) 543.

65 See e.g. Free Trade Agreement \& Economic Integration Agreement, EU-Republic of Korea, Oct. 6, 2010 [hereinafter EU-S. Kor. FTA], Art. 13.10.

66 NAAEC, Art. 2(e).

67 Free Trade Agreement \& Economic Integration Agreement, EU-Japan, July 17, 2018 [hereinafter EU-Japan FTA], Art. 16.11. 
like Article 1114 of NAFTA, which was, at least in part, a reaction to the alarming 'maquiladoras' problem, denounced by environmentalists for years, and finally put down in black and white as a result of the USTR's 'informal' review.

\subsection{Maquiladoras, Hazardous Waste, and the Pollution Haven Package}

During the 196os, the region along Mexico's northern border was facing problematic levels of unemployment and underdevelopment. To address these issues and attract greater foreign investment in the region, in 1965 the federal government established the maquiladora industry. ${ }^{68}$ The maquiladora program essentially established a free-trade zone regime, which allowed for raw materials to be imported in Mexico duty-free as long as their output was exported. ${ }^{69}$ By 1991, there were more than 1871 maquiladora plants along the northern Mexican border, mostly owned or controlled by American corporations. ${ }^{70}$

The maquiladora program played a key role in the country's economic recovery, attracting foreign investment and currency, promoting local employment, and contributing to the overall development of the region. ${ }^{71}$ While beneficial for the Mexican economy, the maquiladora industry was also causing a series of environmental problems, related in particular to the creation of hazardous waste which, when stored improperly and accidentally spilled, risked seeping through the soil and contaminating local groundwater supplies. ${ }^{72}$ These concerns were at the heart of environmentalists' uneasiness about the effect that NAFTA would have on the border region: while it would increase trade between the two countries and expand the maquiladora industry, thus benefitting Mexico's economy, it risked further contributing to the region's environmental degradation ${ }^{73}$ by driving US and Canadian companies to relocate their

68 See Cheryl Schechter and David Frill Jr., 'Maquiladoras: Will the Program Continue' (1992) ${ }_{23}$ Saint Mary's Law Journal 697, 701.

69 Programs of this kind are generally known as 'duty drawback' programs. Ibid., 698. James E. Bailey, 'Free Trade and the Environment-Can NAFTA Reconcile the Irreconcilable' (1992) 8 American University Journal of International Law \& Policy 839, 867.

$70 \quad$ See Schechter and Frill Jr., 'Maquiladoras' (n 68) 699; Roberto A. Sanchez, 'Health and Environmental Risks of the Maquiladora in Mexicali' (1990) 30(1) Natural Resources Journal 163, 164; and Stephen Lerner, 'The Maquiladoras and Hazardous Waste: The Effects under NAFTA' (1993) 6 Transnational Law 255, 258.

71 As of 1993, "the over 1871 maquiladora plants employ over 40o,ooo workers and comprise over fifteen percent of Mexico's total manufacturing labor force." Bailey, 'Free Trade and the Environment' (n 69) 868.

72 Lerner, 'The Maquiladoras and Hazardous Waste' (n 70) 258. US/Mexico Hazardous Waste Work Group, Hazardous Waste Management and Maquiladora Industry Manual (1992), p. 49.

73 Bailey, 'Free Trade and the Environment' (n 69) 868. 
operations in Mexico. The creation of this 'pollution haven' along the Mexican side of the border, in turn, could have encouraged both the United States and Canada to lower their own environmental standards to keep companies at home, leading to a snowballing race to the bottom. ${ }^{74}$

These concerns found an answer in a series of provisions of both NAFTA and NAAEC generally referred to as the 'Pollution Haven Package. ${ }^{75}$ To avoid a situation where Mexico would become a 'pollution haven', NAFTA Article 1114 provides that:

1. Nothing in this Chapter shall be construed to prevent a Party from adopting, maintaining or enforcing any measure otherwise consistent with this Chapter that it considers appropriate to ensure that investment activity in its territory is undertaken in a manner sensitive to environmental concerns.

2. The Parties recognize that it is inappropriate to encourage investment by relaxing domestic health, safety or environmental measures. Accordingly, a Party should not waive or otherwise derogate from, or offer to waive or otherwise derogate from, such measures as an encouragement for the establishment, acquisition, expansion or retention in its territory of an investment of an investor. ${ }^{76}$

The provision, which has often been criticized for being phrased in merely hortatory terms and for lacking an efficient enforcement mechanism, ${ }^{77}$ did

74 See e.g. Robert Housman and Paul M. Orbuch, 'Integrating Environmental and Labor Concerns in the North American Free Trade Agreement: A Look Back and a Look Ahead' (1993) 8(4) American University International Law Review 719, 732.

75 Gary Clyde Hufbauer et al., NAFTA and the Environment: Seven Years Later (Peterson Institute for International Economics, 200o), p. 9.

76 North American Free Trade Agreement, US-Can.-Mex, Dec. 17, 1992, 32 I.L.M. 289 (1993) [hereinafter NAFTA], Art. 1114.

77 The only remedy provided to the aggrieved party is consultation and publicity. See e.g. Steve Charnovitz, 'NAFTA's Social Dimension: Lessons from the Past and Framework for the Future' (1994) VIII(1) International Trade Journal 39, 52; Housman, 'The North American Free Trade Agreement's Lessons' (n 8) 396; and Daniel C. Esty, 'Integrating Trade and Environment Policy Making: First Steps in the North American Free Trade Agreement', in Durwood Zaelke et al (eds.), Trade and the Environment. Law, Economics, and Policy (Island Press, 1993), p. 53. NAAEC seeks to remedy some of these 'shortcomings'. For example, Article 5.1 recasts the hortatory language of NAFTA Article 1114 in legally binding terms by requiring each of the three parties to "effectively enforce its environmental laws." Over time, the term "should" in the original NAFTA evolved into "shall strive to" and finally to "shall" in the recent United States-Mexico-Canada Agreement (USMCA). NAAEC also established two mechanisms to ensure compliance which, however, have proven quite ineffective. See John H. Knox, "The Neglected Lessons of the NAFTA Environmental Regime' (2010) 45(2) Wake Forest Law Review 391, 396-7. 
establish an important new principle: for the very first time, a group of nations had deemed the lack of environmental protection an unacceptable means of encouraging investment and had addressed this "objectional behavior" in a trade agreement. ${ }^{78}$

In the first report prepared by the WTO Committee on Trade and Environment, WTO Members recognized the importance of this principle in the context of trade, rather than investment, noting that "it would be inappropriate for them to relax their existing national environmental standards or their enforcement in order to promote their trade."79 Throughout the years, the 'pollution haven package' has become a constant and essential component of regional trade agreements, often with reference to both trade and investment: the EU and Singapore, for instance, agreed that "it is inappropriate to encourage trade or investment by weakening or reducing the protections afforded in domestic labor and environment laws." ${ }^{80}$ Of course if the parties, on the one hand, wanted to make sure that trade rules were not used to override environmental regulations, on the other, not all environmental laws and standards were allowed - more precisely, those that are "used for protectionist trade purposes" 81 were not-perfectly reflecting the tension underlying any attempt to balance economic and environmental goals.

78 Housman, 'The North American Free Trade Agreement's Lessons' (n 8) 397.

79 World Trade Organization, Committee on Trade and Environment (CTE), Report (1996) of the Committee on Trade and Environment, wT/CTE/W40 (Nov. 7, 1996) [hereinafter CTE 1996 Report], para. 169 (emphasis added).

8o Free Trade Agreement, EU-Singapore [hereinafter EU-Sing. FTA], Art, 13.1, first sentence (emphasis added). Other examples include, e.g., Free Trade Agreement \& Economic Integration Agreement, EU-Colombia-Peru, June 26, 2012 [hereinafter EU-Colom.-Peru FTA ], Art. 277; Free Trade Agreement \& Economic Integration Agreement, United StatesSingapore, May 6, 2003 [hereinafter US-Sing. FTA], Art. 18.2(2); Free Trade Agreement \& Economic Integration Agreement, United States-Chile, June 6, 2003 [hereinafter US-Chile FTA ], Art. 19.2; Free Trade Agreement \& Economic Integration Agreement, United StatesAustralia, May 18, 2004 [hereinafter US-Austl. FTA], Art. 19.2(2); Free Trade Agreement \& Economic Integration Agreement, United States-Republic of Korea, June 30, 2007, Art. 20.3(2); Free Trade Agreement, Turkey-Chile, July 14, 2009, Art. 37(8); Free Trade Agreement \& Economic Integration Agreement, India-Japan, Feb. 16, 2011, Art. 99; Free Trade Agreement \& Economic Integration Agreement, Canada-Colombia, Nov. 21, 2008 [hereinafter Can.-Colom. FTA], Arts. 815 and 1702; Free Trade Agreement, Chile-Malaysia, Nov. 13, 2010, Art. 9.5(2); Free Trade Agreement \& Economic Integration Agreement, Switzerland-China, July 6, 2013, Art. 12.2(2); Free Trade Agreement \& Economic Integration Agreement, Republic of Korea-New Zealand, Mar. 23, 2015 [hereinafter S. Kor.-N.Z. FTA], Art. 16.2(2); Free Trade Agreement, EU-SADC, June 10, 2016 [hereinafter EU-SADC FTA], Art. 9(3); Free Trade Agreement, Canada-Ukraine, July 11, 2016 [hereinafter Can.-Ukr. FTA], Art. 12.5; and EU-Japan FTA, Art. 16.2(2).

81 EU-Sing. FTA, Art, 13.1, second sentence. 


\subsection{This Is Not Solely an International Story}

The "new era" in the trade/environment debate, which began in the mid-199os and was largely inspired by the appearance of the overarching principle of sustainable development, was indeed characterized by the quest for balance between the two regimes. It was no longer possible to pursue the environmental and trade agendas on separate tracks and it became compelling to initiate a fruitful dialogue to reconcile what just a few decades earlier was regarded as entirely irreconcilable. This "new era" has often been described as characterized by a 'greening' of trade law. In particular, the incorporation of environmental sensitivities in the text of NAFTA has been deemed to have "permanently changed the dialogue about trade and the environment," 82 making the agreement the first one of its kind, in directly addressing environmental concerns. ${ }^{83}$

Why was this change of course possible? What had made the North American negotiations 'greener' than all its predecessors? What, even beyond the North American experience, had created the breeding ground for the development of the relationship between trade and the environment towards a more balanced outcome? As argued in the next section-and throughout the whole book-normative changes, while the result of many different and concurring factors, have an indispensable ideational basis, and individuals and communities play a crucial role in creating environments that are more or less conducive to such ideational and normative change.

Before reaching the international plane, most ideas first blossom, spread, and thrive in domestic systems. This is true, for instance, of the ideas conveyed by the Brundtland Report, which reflected and built upon notions initially developed in the United States. ${ }^{84}$ Some domestic systems, for a variety of reasons, the analysis of which are beyond the scope of this inquiry, have provided the trade/environment nexus with an environment more conducive to change than others. And the relative power that these countries were able to exercise

82 Charnovitz, 'NAFTA's Social Dimension' (n 77) 40.

83 Weekly Compilation of Presidential Documents, 1992, at 1425, as quoted in Charnovitz, 'NAFTA's Social Dimension' (n 77) 44. When it was concluded in 1992, William Reilly defined NAFTA as "the greenest trade agreement ever." Carol Browner, then EPA Administrator, claimed without faltering that the Agreement made it "harder to pollute in all three countries," while Congressman Fred Grandy called it "the strongest environmental treaty ever signed ..." See Browner, Former EPA Chief Reilly Push for Support for NAFTA on Capitol Hill, 10 International Trade Reporter 1685 (Oct. 6, 1993). Advertisement, Washington Post, Oct. 26, 1993, at B5.

84 Robert F. Blomquist, “"Clean New World”: Toward an Intellectual History of American Environmental Law, 1961-199o' (1990) 25(1) Valparaiso University Law Review 1. 
in international fora, vis-à-vis countries with an environment comparatively less conducive to change, is precisely what explains a more or less pronounced evolution of the nexus in different contexts.

It should not come as a surprise that NAFTA negotiations could lead to a 'greener' result compared to those that characterized the seven and half years of the Uruguay Round: unlike NAFTA, the GATT of the 199os, and later the WTO, had to accommodate a plethora of divergent voices. According to realist thinking, the actual development of an 'environmental agenda' within trade negotiations largely depends on the relative power and interests of those states that advocate for it - for the most part industrialized nations with large economies. Given the increasing number of developing, and especially least-developed, countries actively participating in the Uruguay Round, the power of 'greener' states, like the US and Northern European countries, proved far less effective than in smaller fora or organizations. ${ }^{85}$

This explains, for instance, why, while the US, the EU, and other industrialized countries introduced the practice of conducting environmental impact assessment of trade agreements, the wTo had instead succeeded in remaining immune to the spreading 'environmental reviews' enthusiasm. This lack of enthusiasm becomes obvious if one looks inside the Committee on Trade and the Environment, where representatives of developing countries did not seem to get on board with the US and European proposals. The representative from India, for instance, clarified more than once that, in his view, conducting environmental reviews "was purely a national prerogative." ${ }^{86}$ As the next section will demonstrate, the different pace of the development of the 'environmental agenda' within multilateral and regional negotiations has led to an asymmetrical evolution of the nexus which can be defined as à la carte.

In 1996, the WTO Committee on Trade and Environment issued its first report, drawn up on the basis of more than $5^{\circ}$ proposals and non-papers submitted by the interested Members. In one of its non-papers, dealing with Item 1 of the agenda - the relationship between the provisions of the multilateral trading system and trade measures for environmental purposes - the EU advanced

\footnotetext{
85 Richard H. Steinberg, 'Trade-Environment Negotiations in the EU, NAFTA, and Wто: Regional Trajectories of Rule Development' (1997) 91 American Journal of International Law 231, 232-3. 
two different proposals. First, the European document suggested to "improve the consistency of the rules of the multilateral trading system taking into account both the commitment expressed in the first preambular paragraph of the Agreement establishing the што and the fact that the environment is already mentioned in several wTO Agreements." ${ }^{\prime 87}$ The second proposal focused instead on the amendment of GATT Article xx, either by including a reference to "measures taken pursuant to specific [Multilateral Environmental Agreements] MEAs" or "in more general terms, to measures necessary to protect the environment." $\$ 8$

These proposals, as well as others advanced by other Members, represent a compromise between the long lists of amendments to the GATT demanded by the environmental community over the previous 20 years, ${ }^{89}$ and the firm conviction of the trade community of the complete adequacy of the existing provisions. The underlying assumption of all proposals requesting amendments to GATT Article Xx was the "belief that by clarifying trade rules and building greater attentiveness to environmental considerations into the GATT, the breadth and depth of trade-environment clashes [could] be reduced."90

To a certain extent, both proposals would be addressed over the years that followed. On the one hand, the newly-created Appellate Body distanced itself from the traditional orientation and ideology that characterized GATT/WTO panels, relying on sources of general international law-including environmental law-even when they were not perfectly in line with the trade agenda. On the other, a new generation of free trade agreements started being negotiated, featuring several references to the environment, including in the text of their GATT-like exception clauses.

87 CTE, Non-Paper by the European Communities on Item 1, Feb. 19, 1996.

88 Ibid.

89 Daniel Esty summarizes the standard menu of concerns as generally including "GATT Article xx reform, import prohibitions, export restraints, product standards, restrictions on production processes and methods, taxes and subsidies, unilateral and extraterritorial actions, and the use of trade penalties to enforce environmental agreements." Daniel C. Esty, Greening the GATT. Trade, Environment, and the Future (Institute for International Economics), p. 99. See e.g. Eliza Patterson, 'GATT and the Environment-Rule Changes to Minimize Adverse Trade and Environmental Effects' (1992) 26(3) Journal of World Trade 99. Peter L. Lallas, Daniel C. Esty, and David J. van Hoogstraten, 'Environmental protection and International Trade: toward Mutually Supportive Rules and Policies' (1992) 16 Harvard Environmental Law Review 271; Rodrigo J. Prudencio and Stewart J. Hudson, 'The Road to Marrakech: An Interim Report on Environmental Reform of the GATT and the International Trade System' (1994) National Wildlife Foundation. 


\subsection{Free Traders and Environmentalists: Together at Last}

To fully understand these developments, one has to consider the way in which the interactions between the trade and environmental community had evolved over the years. On August 12, 1992, while briefing the press immediately after the signature of NAFTA, US Trade Representative Carla Hills noted that if "never has an agreement offered such a balance of economic growth, opportunity, workers' benefits, and environmental sensitivity," this is in large part due to the "efforts and dedication" of the vast US interagency team, composed of negotiators from ten different agencies. For the very first time, environmental officials were included in the trade negotiations. Russell Train, then Chairman of the World Wildlife Fund and former administrator of the US Environmental Protection Agency (EPA) was appointed to the presidential advisory committee, while Carla Hills had appointed similarly prominent environmental leaders to her policy advisory committees. ${ }^{91}$

To really appreciate the importance of these appointments, it suffices to think that only a few years earlier, Carla Hills herself had vocally argued that environmental issues had absolutely no place in trade agreements, ${ }^{92}$ and environmental officials and experts kept watching as the doors of multilateral and regional trade talks closed right in front of them.

However, over the previous few years, many things had changed. The organizations that had been created after the 1970s and that developed and carried the identity of the US environmental movement - such as the Environmental Policy Center, the National Resources Defense Council, and Sierra Club—had established themselves as major actors in the country's political scene, becoming increasingly influential in legislative and administrative politics. ${ }^{93}$ Their

91 They include John Sawhill, President and CEO of the Nature Conservancy and former Secretary of Energy (Industry); Peter Berle, President of the National Audubon Society (Agriculture); John Adams, Executive Director of the Natural Resources Defense Council (Services); Jay Hair, President of the National Wildlife Federation (Investment); and James Strock, Secretary for Environmental Protection of the State of California (Intergovernmental). See Daniel C. Esty, 'Economic Integration and the Environment', in Regina S. Axelrod \& Stacy D. VanDeveer (eds.), The Global Environment. Institutions, Law, and Policy (Sage, 1999), p. 197; Sanford E. Gaines and Albert E. Utton, 'Environmental Laws and Regulations After NAFTA' (1993) 1 US-Mexico Law Journal 199, 200.

92 See John Audley, 'Why Environmentalists Are Angry about the North American Free Trade Agreement', in Zaelke et al (eds.), Trade and the Environment (n 77) 193.

93 RobertJ.Brulle,'EnvironmentalDiscourseandSocial MovementOrganizations:AHistorical and Rhetorical Perspective on the Development of US Environmental Organizations' (1996) 66(1) Sociological Inquiry 58; and Samuel P. Hays, Beauty, Health, and Performance. Environmental Politics in the United States, 1955-1985 (Cambridge University Press, 1989), p. 6o. 
influence, which resulted from a combination of formal participation in the legislative process and informal contacts with the legislators to whom they provided technical advice, was felt in the context of trade negotiations as well. At a January 1991 meeting on Capitol Hill, only four months before Congress would meet to vote on whether to grant the President 'fast-track' authority to negotiate NAFTA, the hall was packed with environmental groups, labor unions, and human rights supporters. ${ }^{94}$ Obtaining 'fast-track' authority, which until then had been a pro forma exercise, was all of a sudden complicated by the presence of these groups, and ultimately became dependent on the government addressing at least some of their concerns. Together, representatives of both governmental and non-governmental environmental groups ended up playing a substantive role in balancing NAFTA's economic goals with environmental concerns. ${ }^{95}$

To better integrate trade and environmental expertise in the development of rules on cross-cutting issues, more permanent fora were created where members of the two communities could exchange ideas, coordinate efforts, and cooperate. In 1994, for instance, the US Trade and Environmental Policy Advisory Committee (TEPAC), co-chaired by the US Trade Representative and the EPA Administrator, was created, to provide policy advice on the intersection of trade and environmental policies. ${ }^{96}$ Within the OECD, environmental issues had been a prerogative of the Environmental Policy Committee, added to the Organization's structure in 1970. After a fruitful dialogue began within the Organization on the intersection between trade and the environment, in 1998, the Joint Working Party on Trade and Environment was established within the Environmental Policy Committee. ${ }^{97}$ And it was the Joint Working Party that published a study in 2001 titled Environmental Goods and Services: The Benefits of Further Global Trade Liberalization, ${ }^{98}$ whose Annex contained a list of environmental goods accompanied by the corresponding Harmonized System nomenclature, ${ }^{99}$ which, together with the list prepared by the Asia-Pacific

\footnotetext{
94 Carolyn L. Deere and Daniel C. Esty (eds.), Greening the Americas. NAFTA's Lessons for Hemispheric Trade (MIT Press, 2002), p. 99.

95 Labor Unions had a similar role during the finals stages of the negotiations, resulting in the introduction of a 'labor' package within the text of NAFTA.

$96 \quad$ Deere and Esty (eds.), Greening the Americas (n 94) 517.

97 OECD, International Environmental Issues and the OECD 1950-200o. An Historical Perspective, by Bill L. Long (oECD Publishing, 2000), p. 144.

98 OECD, Environmental Goods and Services: The Benefits of Further Global Trade Liberalization: The Benefits of Further Global Trade Liberalization (OECD Publishing, 2001).

99 International Convention on the Harmonized Commodity Description and Coding System, June 14, 1983, 1503 U.N.T.S. 3. The Convention contains more than 5,000 six-digit
} 
Economic Cooperation (APEC) countries, constituted the point of departure for negotiations on liberalizing trade in environmental goods and services.

Furthermore, the conditions that had allowed the trade community to remain an exclusive club, such as the homogeneity of its membership, the supposedly technical nature of the subject, and the consequent media indifference, had begun to vanish. Trade disputes, especially those that dealt with non-trade issues, started making the front pages of the New York Times, the Guardian, and many other papers. ${ }^{100}$ Maintaining the previous clubiness had become more and more difficult. The result was the beginning of a dialogue between the trade and environmental community: rather than talking past each other, they started talking to one another and, once they started learning each other's language and values, a fruitful conversation could finally begin. As a result, the environmental community played a key role in 'greening' the final months of the Uruguay Round when, as described by a UsTR official, environmental non-governmental organizations (NGO s) "were briefed every night and became heavily involved in proposing alternate formulations."101

However, at the same time, the WTO membership had become larger and developing countries, which had been given little vote in the past, had become increasingly important players, at least collectively. ${ }^{102}$ It should then be no surprise if the level of institutional integration between the trade and environmental communities, and the resulting influence on the evolution of the nexus, are 'softer' within the wто than in certain domestic and regional experiences.

\section{2}

\section{The Committee on Trade and Environment: WTo's 'Softer' Version of Institutional Integration}

During one Uruguay Round negotiating meeting in December 199o, Members of the European Free Trade Association (EFTA) requested the GATT Secretariat to re-activate the long-dormant EMIT Group to ensure the effective participation of the GATT in the fast-approaching UN Conference on Environment

subheadings, which may be subdivided further to reflect national administrative and statistical requirements.

100 Joseph Weiler, 'The Rule of Lawyers and the Ethos of Diplomats: Reflections on the Internal and External Legitimacy of Dispute Settlement', in Roger B. Porter et al. (eds.), Efficiency, Equity, and Legitimacy: The Multilateral Trading System at the Millennium (Brookings Institution Press, 2001), p. 337. See also Robert O. Keohane and Joseph S. Nye Jr., 'The Club Model of Multilateral Cooperation and Problems of Democratic Legitimacy', in Porter et al. (eds.), Efficiency, Equity, and Legitimacy, pp. 269-272.

101 Salzman, 'Seattle's Legal Legacy' (n 47) at fn. 74.

102 Jeffrey A. Frankel,' Assessing the Efficiency Gains for Further Liberalization', in Porter et al. (eds.), Efficiency, Equity, and Legitimacy (n 100) 94. 
and Development. ${ }^{103}$ During the final sessions of the Uruguay Round, the role and mandate of the Group spurred heated discussions among the negotiators. While some delegations saw the need to transform the Group into a more permanent mechanism to effectively address the issues that would arise from the interface between trade and the environment, ${ }^{104}$ others - in particular developing countries - wanted to avoid giving the environment a permanent place within the new Organization, arguing that it was a 'trade' organization after all, and fearing that mainstreaming environmental discussions in the Wто might be used to limit their development options. ${ }^{105}$ Eventually, developing countries agreed to the creation of the Committee, provided that its agenda reflected their concerns as well. On April 15, 1994, along with the Final Act of the Uruguay Round, the parties adopted the Decision on Trade and Environment, which established the Committee on Trade and Environment or CTE. ${ }^{106}$

103 Proposal to convene the EMIT Working Group, submitted by member countries of the European Free Trade Association, in Statement on Trade and the Environment. See MTN. TNC/W/47 (Dec. 3, 1990). What these northern European countries had at heart when they requested to reinvigorate the Group, however, was not the environment as such. Rather, despite their 'green' reputation, they simply wanted the GATT to confront "the rising tide of environmental measures and international environmental agreements" because many used trade measures to realize their objectives. Trade interests, hence, rather than environmental concerns, led to the convening of the Group, as evidently demonstrated by its mandate: although certain parties-in particular the EU and the US - had been criticizing the original mandate of the Group because too narrow, the Group had been careful to "ensure that the scope of its discussions remained well within its mandate and GATT's competence, namely the trade-related aspects of environment policies which may result in significant trade effects for GATT contracting parties." C/M/ 247 (Mar. 5, 1991), p. 22, as quoted in Gregory C. Shaffer, 'The World Trade Organization under Challenge: Democracy and the Law and Politics of the WTO's Treatment of Trade and Environment Matters' (2001) 25 Harvard Environmental Law Review 1, 17, fn. 51. See also Report by the Chairman of the Group on Environmental Measures and International Trade presented to the Contracting Parties at their Forty-ninth Session, GATT B.I.S.D. (40th Supp.), p. 75, para. 9 (1995) (reporting to the January 25 and 261994 meeting of GATT members, the work of the EMIT Working Group in 1993, L/7402).

104 Manisha Sinha, 'An Evaluation of the wTо Committee on Trade and Environment' (2013) 47(6) Journal of World Trade 1285, 129 o.

105 Prudencio and Hudson, 'Suggestions on an Environmental Reform Agenda' (n 89) 10; Shaffer, 'The World Trade Organization under Challenge' (n 103) 23; and Esty, Greening the GATT (n 89) 37.

106 Decision on Trade and Environment, April 14, 1994, Marrakesh Agreement Establishing the World Trade Organization Annex IC, 33 I.L.M. 1267 [hereinafter Decision on Trade and Environment]. See Gregory Shaffer, 'The Nexus of Law and Politics: The wTo's Committee on Trade and Environment', in Richard Steinberg (ed.), The Greening of Trade Law 81 (Rowman \& Littlefield Publishers, 2002), p. 87. 
The creation of the CTE was immediately seen by many environmentalists as a hopeful change in the GATT's approach to the trade/environment nexus. The Decision on Trade and Environment clarified the terms of reference of the Committee, which differed greatly from the ones drafted for the EMIT Group: the aim of the CTE was not anymore to simply assess the potentially negative impacts of environmental measures on trade, but rather to contribute to making international trade and environmental measures mutually supportive. To this end, the CTE was asked to

(a) identify the relationship between trade measures and environmental measures, in order to promote sustainable development; and

(b) make appropriate recommendations on whether any modifications of the provisions of the multilateral trading system are required, compatible with the open, equitable and non-discriminatory nature of the system ...107

Unfortunately, despite the initial high hopes for the work of the Committeesome even predicted it would solve "all outstanding trade and environment matters within two years of the entry into force of the wTO [Agreement]"108 — the

107 Ibid. Within those terms of reference, the Committee was initially expected to address the following matters: "i) the relationship between the provisions of the multilateral trading system and trade measures for environmental purposes, including those pursuant to multilateral environmental agreements; ii) the relationship between environmental policies relevant to trade and environmental measures with significant trade effects and the provisions of the multilateral trading system; iii) the relationship between the provisions of the multilateral trading system and charges and taxes for environmental purposes and requirements for environmental purposes relating to products; iv) the provisions of the multilateral trading system with respect to the transparency of trade measures used for environmental purposes and environmental measures and requirements which have significant trade effects; v) the relationship between the dispute settlement mechanisms in the multilateral trading system and those found in multilateral environmental agreements; and vi) the effect of environmental measures on market access, especially in relation to developing countries, in particular to the least developed among them, and environmental benefits of removing trade restrictions and distortions."

108 Action Agenda: Trade and the Environment, Resolution Adopted Unanimously by the 8th GLOBE International General Assembly (Mar. 2, 1994), as quoted in Steve Charnovitz, 'A Critical Guide to the wTo's Report on Trade and Environment' (1997) 14(2)Arizona Journal of International \& Comparative Law 341. Along the same lines, the Clinton Administration promised that the СтE would "assist efforts to reach international agreements on environmental issues that affect the entire world, such as ozone depletion, global climate change and biodiversity." Office of The US Trade Representative, Uruguay Round-Jobs for the United States, Growth for the World 19 (1994). 
first results were quite disappointing. ${ }^{109}$ Two years after its creation, rather than solving all "outstanding matters," the СтE issued its first report and it became instantly clear that the road ahead was still long and rocky:110 After a "grueling negotiating process, culminating in a 36 -hour marathon session where the concluding portion of the report was negotiated line-by-line," the report's conclusions merely called for "further work" on all 11 agenda items. ${ }^{111}$

Despite this criticism, the Committee did play a key role in advancing the trade and environment debate, by serving as a laboratory to open up wто's internal process to the public, and as a venue where national officials from trade and environment ministries could get together and where representatives from MEA s Secretariats and other international environmental organizations could regularly meet with trade officials. ${ }^{112}$ The value of such socialization should by no means be underestimated, as it has allowed for constant communication between the two communities, acting as a breeding ground for mutual coordination and cooperation. ${ }^{113}$ It was precisely because the two communities had been pursuing their work on separate tracks for years that they had not been able to move past their deeply rooted differences in goals, assumptions, procedures, and traditions. As the delegates representing a state

109 See e.g. Charnovitz, 'A Critical Guide' (n 108) 342; Thomas J. Shoenbaum, 'International Trade and Protection of the Environment: The Continuing Search for Reconciliation' (1997) 91 American Journal of International Law 268, 269-70.

110 CтE 1996 Report. Several scholars have assessed the work of the CTE over the first few years. See e.g. Geert Van Calster, 'The World Trade Organisation Committee on Trade and Environment: Exploring the Challenges of the Greening of Free Trade' (1996) European Environmental Law Review 44; Kristin Woody, 'The World Trade Organization's Committee on Trade and Environment' (1996) 8 Georgetown International Environmental Law Review 459; Richard G. Tarasofsky, 'The wTo Committee on Trade and Environment: Is It Making a Difference?' (1999) 3 Max Planck Yearbook of United Nations Law 471; and Sinha, 'An Evaluation' (n 104).

111 Shaffer, 'The World Trade Organization under Challenge' (n 103) 36.

112 Shaffer, 'The Nexus of Law and Politics' (n 106) 101; Charnovitz, 'The wTo's Environmental Progress' (n 4) 690.

113 Throughout the years, a number of international environmental institutions have been granted observer status in the CTE, as well as in several other wTO bodies. The Secretariats that enjoy observer status in the сте include those of the СвD, the Convention of International Trade in Endangered Species of Wild Fauna and Flora (Cites), the International Commission for the Conservation of Atlantic Tuna (ІССAT) and the United Nations Framework Convention on Climate Change (UNFCCC). For a complete list, see https://www.wto.org/english/thewto_E/igo_obs_e.htm. Mutual observership represents one of the several forms of cooperation between trade and environmental organizations, listed in a document prepared by the wTO Secretariat entitled Existing Forms of Cooperation and Information Exchange Between UNEP/MEAs and the WTO. See TN/TE/s/ 2/Rev.2 (Jan. 16, 2007). 
in the WTO are not usually the same as those acting for the very same state in the context of environmental organizations, ${ }^{114}$ lack of communication and coordination risks leading to conflicting provisions. ${ }^{115}$ If trade and environmental goals need to be pursued in a mutually supportive manner, however, this course of action is no longer sustainable.

Outside of the СтЕ, a certain level of 'greening' can be found in the work of the newly created Appellate Body. Here, seven judges external to the trade policy elite were given the opportunity to push the nexus ahead towards further integration.

\subsection{Seven 'Faceless Foreign Judges'}

This was truly extraordinary language, and a constitutional door opener for approaches that require a broader perspective than just the four corners of the very extensive GATT/WTO treaty language. ${ }^{116}$

JOHN JACKSON, 2005

The language John Jackson was referring to in this often-quoted passage belongs to the Appellate Body Report in the landmark US —Shrimps decision. On this occasion, the Appellate Body admonished the first level panel for focusing only on trade, without taking in due account other fundamental policy goals, and entertained these other goals in the process of interpreting the chapeau of GATT Article Xx. ${ }^{117}$ By doing so, the Appellate Body not only criticized the panel's approach but, most importantly, repudiated the traditional approach to environmental trade measures in the GATT/WTO system since the first Tuna/Dolphin case. ${ }^{118}$

This traditional approach assumed a priori, and without any textual basis, that "unilateral measures that conditioned market access on the policies of the

114 See Joost Pauwelyn, Conflict of Norms in Public International Law (Cambridge University Press, 2003), p. 15.

115 See e.g. the relationship between Articles 27, 29, and 62 of the Agreement on Trade-Related Intellectual Property Rights (TRIPS) Agreement, and Article 15 of the СвD. See Nuno Pires de Carvalho, 'Requiring Disclosure of the Origin of Genetic Resources and Prior Informed Consent in Patent Applications Without Infringing the TRIPS Agreement: The Problem and the Solution' (2000) 2 Washington University Journal of Law and Policy 371.

116 John H. Jackson, 'Justice Feliciano and the WTO Environmental Cases: Laying the Foundations of a "Constitutional Jurisprudence" with Implications for Developing Countries', in Charnovitz et al (eds.), Law in the Science of Human Dignity 29 (Cambridge University Press, 2005), p. 40.

117 Ibid.

118 See Robert Howse, 'The Appellate Body Rulings in the Shrimp/Turtle Case: A new Legal Baseline for the Trade and Environment Debate' (2002) 27 Columbia Journal of Environmental Law 491, 499. 
exporting countries were, as a matter of general principle, not justifiable under Article XX."119 Reversing this finding, the Appellate Body stated that

It is not necessary to assume that requiring from exporting countries compliance with, or adoption of, certain policies ... prescribed by the importing country, renders a measure a priori incapable of justification under Article Xx. Such an interpretation renders most, if not all, of the specific exceptions of Article $\mathrm{xx}$ inutile, a result abhorrent to the principles of interpretation we are bound to apply. ${ }^{120}$

In its interpretation of the chapeau, the Appellate Body relied on the Preamble to the wто Agreement, which explicitly listed 'sustainable development' as one of the objectives of the Agreement, to be pursued "seeking both to protect and preserve the environment,"121 and which added "colour, texture, and shading" to the interpretation of trade provisions. ${ }^{122}$ Moreover, the Appellate Body relied on certain developments that occurred after the end of the Uruguay Round and which helped elucidate "the objectives of the members with respect to the relationship between trade and the environment" such as, among others, the establishment of the CTE. ${ }^{123}$ In contrast with the reasoning of the panel, which concluded that "the provisions of the GATT are essentially turned toward liberalization of access to markets on a non-discriminatory

119 See Panel Report, United States_Import Prohibition of Certain Shrimp and Shrimp Products WT/DS58/R (May 15, 1998) [hereinafter US-Shrimps], para. 7.50. Howse, 'The Appellate Body Rulings' (n 118) 498.

120 Appellate Body Report, US—Shrimps wT/DS58/AB/R (Oct. 12, 1998), para. 121.

121 The Uruguay Round negotiators were not the first nor the last to introduce references to sustainable development and the environment in a purely economic treaty. A very similar wording can be found in the preamble of NAFTA and, even before, in 1986, the Single European Act (SEA) had inserted a title on the 'Environment' into the EEc Treaty, which did not contain any provisions on the environment or on the possible role of the Community in its protection. With this new Title, the Act essentially gave a constitutional base to the Community's environmental policy, defining its objectives as preserving, protecting, and improving the quality of the environment; contributing towards protecting human health; and ensuring a prudent and rational utilization of natural resources. Single European Act Amending the Treaties Establishing the European Communities, July 1, 1987, 1987 O.J. L 169/1 [hereinafter SEA]. See Title vir in Part Three of the EEC Treaty, in particular Article 13or(1), as amended by the SEA. See Dirk Vandermeersch, 'The Single European Act and the Environmental Policy of the European Economic Community', in Ludwig Kramer (ed.), European Environmental Law: A Comparative Perspective (Routledge, 2003).

122 Appellate Body Report, US —Shrimps, para. 153.

123 Ibid., para. 154. 
basis," ${ }^{24}$ the Appellate Body recognized the delicate nature of the chapeau as a means to strike a balance between two equally important rights. ${ }^{125}$

While early GATT panel holdings had rendered environmental exceptions essentially unusable, ${ }^{126}$ the Appellate Body explicitly acknowledged that, sustainable development being one of the objectives of the WTO Agreement, Article xx should be read so as to mediate between the right to an open, nondiscriminatory, and equitable multilateral trading system on the one hand, and the right to act for the protection of the environment, and the promotion of sustainable development on the other. ${ }^{127}$

With this decision, and others before, ${ }^{128}$ the Appellate Body cut a clear break from the traditional approach of GATT and WTO panels. Some scholars have ascribed this departure to the Appellate Body's composition, which was remarkably different from the one that characterized both GATT and WTO panels. ${ }^{129}$ The seven original and founding members of the Appellate Body, who first worked together at "a round table in a corner room of a quiet wing of the Italianate Villa that serves as the global headquarters of the Wто in Geneva," were: Julio Lacarté-Muro of Uruguay, Claus-Dieter Ehlermann of Germany, Florentino Feliciano of the Philippines, Said El-Naggar of Egypt, Mitsuo Matsushita of Japan, Christopher Beeby of New Zealand, and James Bacchus of the United States. ${ }^{130}$ With the exception of Lacarté-Muro, none of these seven 'faceless foreign judges', as journalists often referred to them, had any particular ties with the trade policy elite. Unlike those sitting in GATT ad-hoc panels, these seven judges had been chosen among "distinguished generalist jurists, not eminent experts in GATT/WTO law."131 It should be no

124 Panel Report, US —Shrimps, para. 7.42.

125 The Appellate Body stated that "[t]he task of interpreting and applying the chapeau is, hence, essentially the delicate one of locating and marking out a line of equilibrium between the right of a Member to invoke an exception under Article Xx and the rights of other Members under varying substantive provisions (e.g. Art. XI) of the GATT 1994, so that neither of the competing rights will cancel out the other." Appellate Body Report, US-Shrimps, para. 159 .

126 Charnovitz, 'The wTo's Environmental Progress' (n 4) 695-6.

127 Appellate Body Report, US — Shrimps, para. 154.

128 Appellate Body Report, Japan-Taxes on Alcoholic Beverages, wT/Ds8/AB/R (Nov. 1, 1996) [hereinafter Japan-Alcoholic Beverages II]; European Communities-Customs Classification of Certain Computer Equipment, WT/DS62/AB/R (June 5, 1998).

129 See e.g. Robert Howse, 'The World Trade Organization 20 Years On: Global Governance by Judiciary' (2016) 27(1) European Journal of International Law 9, and Michael Trebilcock et al. (eds.), The Regulation of International Trade (Routledge, 2005), pp. 381-425.

130 James Bacchus, 'Table Talk: Around the Table of the Appellate Body of the World Trade Organization' (2002) 35(4) Vanderbilt Journal of Transnational Law 1021, 1022-23.

131 Howse, 'The World Trade Organization 20 Years On' (n 129) 27. 
surprise then if, rather than following the trade elite dicta, they adopted a rather different approach, "employing normative benchmarks and legal standards and sources from outside the domain of GATT/WTO law, unrelated to and sometimes in tension with GATT 'collective wisdom,"' and relying heavily on the rules of interpretation provided by the Vienna Convention on the Law of Treaties (VCLT). ${ }^{132}$

Unlike GATT panels, WTO adjudicators are explicitly required to invoke the rules of interpretation of treaties as a source to clarify wTO Agreements. ${ }^{133}$ Such 'rules of interpretation' are contained in Articles 31 and 32 of the VCLT and they require adjudicators to interpret every treaty "in good faith in accordance with the ordinary meaning to be given to the terms of the treaty in their context and in the light of its object and purpose."134 The principle of sustainable development and the objective of preserving and protecting the environment are now part of the "context, object and purpose" of the covered agreements and should inform the interpretation of any other GATT/WTO rule accordingly. And in fact, in US - Shrimps, both the panel and the Appellate Body were required to take into account the "context, object and purpose" of the covered agreements when interpreting the chapeau of GATT Article Xx. However, the different approach of the two bodies can hardly be missed. On the one hand, the panel concluded that "while the WTO preamble confirms that environmental considerations are important for the interpretation of the WTO agreement, the central focus ... remains the promotion of economic development through trade." 135 On the other, the Appellate Body gave equal importance to the rights of the Members under the substantive-trade liberalization-provisions of the GATT and its exceptions, clarifying that "neither of the competing rights [should] cancel out the other."136

\footnotetext{
132 Ibid., at 31 .

133 Understanding on Rules and Procedures Governing the Settlement of Disputes, Apr. 15, 1994, Marrakesh Agreement Establishing the World Trade Organization, Annex 2, 1869 U.N.T.S. 401 [hereinafter DSU], Art. 3.2. In US —Gasoline and US —Shrimps, the Appellate Body criticized the panel for not following all the steps in applying the customary rules of interpretation of public international law and for overlooking "a fundamental rule of treaty interpretation." Appellate Body Report, United States-Standards for Reformulated and Conventional Gasoline, WT/DS2/AB/R (Apr. 29, 1996) [hereinafter US—Gasoline], 1617; Appellate Body Report, US —Shrimps, para. 115.

134 Vienna Convention on the Law of Treaties, May 23, 1969, 1155 U.N.T.S. 331 [hereinafter VCLT], Article 31.1.

135 Panel Report, US —Shrimps, para. 7.42.

136 Appellate Body Report, US—Shrimps, para. 154.
} 
Moreover, together with the context, Article 31(3)(c) of the vCLT demands that "any relevant rules of international law applicable in the relations between the parties" be taken into account, and the Appellate Body has in many instances drawn from the body of law which has developed outside the context of the GATT, including environmental principles and norms, in its interpretation of WTO norms. ${ }^{137}$

A comprehensive analysis of the composition of the Appellate Body at different times and its impact on the interpretation of WTO provisions is beyond the scope of this contribution. It is interesting, however, to note a concomitance between, on the one hand, an Appellate Body composed of members outside of the trade policy elite, at least in its founding membership, and on the other, decisions in trade/environment cases that seem to depart from the neoliberal approach typical of the elite itself. Besides, this is not the first nor the sole example of the influence that the composition of a judicial body

137 See e.g. US - Shrimps (CITES and UnClos) and EC — Bananas III (Lomè Convention). Appellate Body Report, US-Shrimps; European Communities-Regime for the Importation, Sale and Distribution of Bananas, WT/DS27/AB/R (Sept. 9, 1997). In a paper presented at the GATT Symposium on Trade, Environment and Sustainable Development in July 1994, Philippe Sands had hoped that "the new wTo language [would] allow wTO panels to take into account the body of law which has developed outside the context of the GATt." Philippe Sands, GATT 1994 and Sustainable Development: Lessons from the International Legal Order, Papers presented at the GATT Symposium on Trade, Environment and Sustainable Development, July 28, 1994, 27-30, 28. But see the Panel Report in $E C$-Biotech, where the panel refused to take into account as means of interpretation the СвD and the Protocol on Biosafety because, according to vсLT Article 31.3(c), there shall be taken into account "any relevant rules of international law applicable in the relations between the parties," and not all the parties to the disputes were parties to these meAs. Panel Report, European Communities-Measures Affecting the Approval and Marketing of Biotech Products, WT/DS291/R (Sept. 29, 2006). Howse and Horn argue that this difference in approach between the Appellate Body and the Panel can "come down to the [Appellate Body's] interest in enfranchising environmental interests and constituencies in wто dispute settlement, and the Panel's concern (possibly reflecting the insider perspective of the wTо Secretariat, which has a large influence in the drafting of Panel decisions) to enfranchise those interests and constituencies as little as possible." Robert L. Howse and Henrik Horn, 'European Communities-Measures Affecting the Approval and Marketing of Biotech Products' (2009) 8(1) World Trade Review 49, 6o. See Joost Pauwelyn, 'The Role of Public International Law in the wто: How Far Can We Go?' (2001) 95(3) American Journal of International Law 535. As noted by Joel Trachtman, "the Appellate Body has not yet definitively addressed the question as to whether the other relevant rules of international law used in interpretation ... are limited to those to which all members subscribe, or whether they only need bind the parties to the particular dispute." Joel P. Trachtman, 'wTo Trade and Environment Jurisprudence: Avoiding Environmental Catastrophe' (2017) 58(2) Harvard Journal of International Law 273, 303. 
can have on a line of decisions. Another example-outside of the environmental realm this time-is offered by the changing composition of the US Supreme Court. For instance, in 1937, after years of frequently striking down national laws as exceeding the proper scope of the commerce power, the US supreme Court started showing great deference to congressional action under the commerce power and for nearly six decades no law was struck down on Commerce Clause grounds. ${ }^{138}$ In those years there had been rapid changes in the composition of the Court. From 1937 through 1941, President Roosevelt made several appointments to the Court-Justices Black, Reed, Frankfurter, Douglas, Murphy, Byrnes, and Jackson — cementing the dominance of a deferential judicial stance toward Congress' commerce power. A simple change in the Justices sitting on the bench let several state laws survive the Court's scrutiny. Just like those seven Justices shared a certain deferential judicial stance toward Congress' commerce power, which led to a line of decisions interpreting the Clause broadly, so an Appellate Body composed by international jurists rather that trade technocrats, led to a different-less trade-centeredinterpretation of GATT Article XX in cases such as US — Shrimps, EC - Asbestos, and EC-Hormones. ${ }^{139}$

\subsection{Finding Balance through Interpretation}

The approach adopted by the Appellate Body allowed for an increasingly expansive interpretation of the exception clauses applicable inter alia to the environment. As such, the individual subparagraphs of Article xx have been given a progressively more expansive reading. For many years, GATT panels had adopted a restrictive interpretation of the 'necessary' requirement under Article $\mathrm{xx}(\mathrm{b})$, applying the so-called 'least trade restrictive' test. ${ }^{140}$ The latter was very narrow and did not acknowledge the political reality of environmental policy-making processes. ${ }^{141}$ After the establishment of the wTO, however,

138 Noah Feldman and Kathleen M. Sullivan, Constitutional Law (Foundation Press, 2013), p. 131.

139 See e.g. B.S. Chimni, 'wTo and Environment. Shrimp-Turtle and EC-Hormones Cases' (2000) 35(20) Economic and Political Weekly 1752; Robert Howse and Elizabeth Tuerk, 'The WTо Impact on Internal Regulations-A Case Study of the Canada-EC Asbestos Dispute', in George A. Bermann and Petros C. Mavroidis (eds.), Trade and Human Health and Safety (Cambridge University Press, 2006); Andrew Green and Tracy Epps, 'The wTo, Science, and the Environment: Moving Towards Consistency' (2007) 10(2) Journal of International Economic Law 285; Charnovitz, 'The wTo's Environmental Progress' (n 4).

140 See Chapter 3, Section 3.2.

141 Janine Ferretti, 'The Internalization of Environmental Costs and the Implications for the Trading System', Papers presented at the GATT Symposium on Trade, Environment and Sustainable Development, July 28, 1994, 33, 36 . 
the Appellate Body in Korea-Beef introduced a new test for 'necessity',142 clarifying that the term 'necessary' is not limited to measures that are 'indispensable.' ${ }^{143}$ For measures that are not indispensable to achieve the objective set out in Article Xx(b), the 'necessary' standard is to be judged in every case through a process of weighing and balancing a series of factors. ${ }^{144}$

The factors to be weighed and balanced are the importance of the values furthered by the challenged measure, the contribution of the measure to the realization of such values, and the restrictive impact of the measure on international trade flows. ${ }^{145}$ In this context, the Appellate Body Report in Brazil-Tyres explicitly referred to measures adopted to tackle environmental

142 In Korea-Beef, like a few years later in Brazil—Tyres, the Appellate Body was required to interpret the word 'necessary' under Article xx(d), but the same reasoning has been considered applicable to $\mathrm{xx}(\mathrm{b})$. Appellate Body Report, Korea-Measures Affecting Imports of Fresh, Chilled and Frozen Beef, wT/Ds161/AB/R (Dec. 11, 2000) [hereinafter KoreaBeef]; Appellate Body Report, Brazil—Measures Affecting Imports of Retreaded Tyres, wT / DS332/AB/R (Dec. 3, 2007) [hereinafter Brazil—Tyres]. This test was applied to Article $\mathrm{xx}(\mathrm{b})$ for the first time by the Appellate Body in EC-Asbestos. See Appellate Body Report, European Communities-Measures Affecting Asbestos and Products Containing Asbestos, WT/Ds135/AB/R (Mar. 12, 2001) [hereinafter EC-Asbestos], para 172. Nevertheless, the importation of the Article $\mathrm{xx}(\mathrm{d})$ test to $\operatorname{Article} \mathrm{xx}(\mathrm{b})$ has been criticized by some scholars. See e.g. Anupam Goyal, The WTO and International Environmental Law (Oxford University Press, 2006), pp. 139-140.

143 In Korea-Beef, the Appellate Body continued explaining that "[a]s used in Article $\mathrm{xx}(\mathrm{d})$, the term 'necessary' refers, in our view, to a range of degrees of necessity. At one end of this continuum lies 'necessary' understood as 'indispensable'; at the other end, is 'necessary' taken to mean as 'making a contribution to'. We consider that a 'necessary' measure is, in this continuum, located significantly closer to the pole of 'indispensable' than to the opposite pole of simply 'making a contribution to'." Appellate Body Report, Korea—Beef, para. 161. See also Appellate Body Report, Brazil-Tyres, para. 141.

144 Charnovitz, 'The wTo's Environmental Progress' (n 4) 697-8. This new test has then been confirmed in several other cases, such as: Appellate Body Report, China-Measures Affecting Trading Rights and Distribution Services for Certain Publications and Audiovisual Entertainment Products, WT/DS363/Aв/R (Dec. 21, 2009) and China-Measures Related to the Exportation of Various Raw Materials, WT/DS394/AB/R (Jan. 30, 2012) [hereinafter China-Raw Materials].

145 Appellate Body Report, Korea-Beef, para. 164; Appellate Body Report, Brazil—Tyres, paras. 142-3; and Appellate Body Report, Appellate Body Report, United States—Measures Affecting the Cross-Border Supply of Gambling and Betting Services, wT/DS285/AB/R (Apr. 7 , 2005) [hereinafter US — Gambling], para. 306. Note the departure from the 'traditional' approach adopted up until the panel report in Korea-Beef: "To demonstrate that the dual retail system is 'necessary', Korea has to convince the Panel that no alternative measure consistent with the Wто Agreement is reasonably available at present in order to deal with misrepresentation in the retail beef market as to the origin of beef." Panel Report, Korea-Beef, wT/Ds161/R (July 31, 200o), para. 659. 
problems - climate change and global warming in particular. In this regard, the Appellate Body concluded that even if the contribution of a measureincluding an import ban - to these objectives is not immediately observable, it can still be justified under Article $\mathrm{xx}(\mathrm{b})$ on the basis of a demonstration that it is "apt to produce a material contribution to the achievement of its objective," considering in particular that

certain complex public health or environmental problems may be tackled only with a comprehensive policy comprising a multiplicity of interacting measures. In the short-term, it may prove difficult to isolate the contribution to public health or environmental objectives of one specific measure from those attributable to the other measures that are part of the same comprehensive policy. Moreover, the results obtained from certain actions ... can only be evaluated with the benefit of time. ${ }^{146}$

This test appears to be far less stringent than the 'least trade restrictive' test in terms of the kind of relationship that is required between the measure adopted and the policy objective pursued, thus expanding the policy space provided for environmental protection measures. ${ }^{147}$

Even more so if one looks at how the determination of the second element of the test- the existence of a less trade-restrictive alternative-has evolved over time: to be viable, the alternative needs to not only allow for the same level of protection as that desired by the Member adopting the measure, but it also needs to be technically and financially feasible. ${ }^{148}$ Moreover, the allocation of the burden of proof in presenting the panel with a viable alternative provides the member defending the environmental measure with a further advantage: while under the 'least trade restrictive' test, it was understood that

146 Appellate Body Report, Brazil—Tyres, para. 151. A few years prior, in US—Gasoline, the Appellate Body had reached similar conclusions in the context of GATT Article xx (g): "in the field of conservation of exhaustible natural resources, a substantial period of time, perhaps years, may have to elapse before the effects attributable to implementation of a given measure may be observable." Appellate Body Report, US - Gasoline, 21.

147 Gabrielle Marceau and Julian Wyatt, 'The wTo's Efforts to Balance Economic Development and Environmental Protection: A Short Review of Appellate Body Jurisprudence' (2013) 1(1) Latin American Journal of International Trade Law 291, 300.

148 In US - Gambling, the Appellate Body recognized that an alternative measure may be found not to be 'reasonably available' not only where it does not achieve the responding Member's chosen level of protection but also "where it is merely theoretical in nature, for instance, where the responding Member is not capable of taking it or where the measure imposes an undue burden on that member, such as prohibitive costs or substantial technical difficulties." Appellate Body Report, US_Gambling, para. 308. 
the country invoking Article Xx would have to prove the absence of an alternative, ${ }^{149}$ in Brazil-Tyres — and even before in US - Gambling - the Appellate Body clarified that "while the responding Member must show that a measure is necessary, it does not have to show, in the first instance, that there are no reasonably available alternative to achieve its objectives."150

Article $\mathrm{xx}(\mathrm{g})$ has been characterized by a similar increasingly expansive interpretation. In US - Shrimps, the Appellate Body, while interpreting Article $\mathrm{xx}(\mathrm{g})$, concluded that the provision could not be "read as referring only to the conservation of exhaustible mineral or other non-living natural resources."151 Rather than the finding itself, which was not entirely new to the GATT/WTO system, ${ }^{152}$ the reasoning of the Appellate Body is of particular interest. As a matter of fact, this conclusion was motivated not solely by the language of the Wто Preamble ${ }^{153}$ but equally by the fact that the Brundtland Report denounced "growing scientific consensus that species are disappearing at rates never before witnessed on the planet,"154 and that "all of the seven recognized species of sea turtles are today listed in Appendix 1 of [the Convention on International Trade in Endangered Species of Wild Fauna and Flora] CiTEs." 155 This line of reasoning is even more impressive if one stops for a moment to think that, only ten years before, the GATT panel in Canada-Salmon and Herring had refused to even look at the United Nations Convention on the Law of the Sea (UNCLOS) because its mandate was "limited to the examination of Canada's measures in the light of the relevant provisions of the GATT."156

149 See e.g. Report of the GatT Panel, United States-Section 337 of the Tariff Act of 1930, B.I.S.D. $36 \mathrm{~S} / 345,385$ (Nov. 7,1989 ), para. 5.27 .

150 Appellate Body Report, US—Gambling, para. 309; Appellate Body Report, Brazil—Tyres, para. 156.

$15^{1}$ Appellate Body Report, US —Shrimps, para. 131.

152 In the 1988 gatt Panel Report on Canada-Salmon and Herring, the Panel agreed with the parties that salmon and herring stocks were 'exhaustible natural resources'. Report of the Panel, Report of the GatT Panel, Canada-Measures Affecting Exports of Unprocessed Herring and Salmon, L/6268-35S/98 (Mar. 22, 1988) [hereinafter Canada-Herring and Salmon], para. 4.4.

153 Ibid.

154 Brundtland Report, p. 13, as quoted in fn. 106 of the Appellate Body Report, US - Shrimps.

155 Appellate Body Report, US —Shrimps, para. 132. Besides Cites, the Appellate Body relied on several other environmental treaties to support this argument, including UNCLOS, the CBD, Agenda 21, and the Resolution of Assistance to Developing Countries adopted in conjunction with the Convention on the Conservation of Migratory Species of Wild Animals. See Appellate Body Report, US —Shrimps, para. 130.

156 Report of the GatT Panel, Canada-Herring and Salmon, para. 5.3. 
Regarding the second prong of this subparagraph - that a measure be "relating to" the conservation of exhaustible natural resources - the Appellate Body seems to have distanced itself from the traditional GATT jurisprudence, which had given the term a strict meaning of "primarily aimed at" for several years. In US Shrimps, the Appellate Body seemed to abandon the interpretation of "relating to" as "primarily aimed at," to embrace a more nuanced approach, examining the relationship between the general structure of the measure and the conservation policy goal it purports to serve, and concluding that the means were "reasonably related" to the ends. ${ }^{157}$ Since then, the "relating to" requirement has been defined as a "close and genuine relationship of ends and means."158

Finally, in the context of the same dispute, the Appellate Body adopted a new approach with regards to the issue of amicus curiae briefs, by holding that both panels and the Appellate Body have the authority to accept and examine amicus briefs from non-state actors, including environmental NGO s. While recognizing, in line with the panel's reasoning, that the panel's authority to seek information and technical advice does include "the authority to decide not to seek such information or advice," the Appellate Body concluded that Article 13 of the Dispute Settlement Understanding (DSU) does not contain the prohibition to accept information which has been submitted without having been requested by the panel. ${ }^{159}$ The same seems to apply to the Appellate Body, considering that it did accept an unsolicited brief precisely in US —Shrimps. ${ }^{160}$

157 Ibid., paras. 136-7, and 141-2. See Charnovitz, 'The WTo's Environmental Progress' (n 4) 701.

158 Appellate Body Report, US -Shrimps, para. 136; Appellate Body Report, China-Raw Materials, paras. 356, 361. See Trachtman, 'wTo Trade and Environment Jurisprudence' (n 137) $295^{-6 .}$

159 Appellate Body Report, US — Shrimps, paras. 104 and 108.

16o Later in US - Lead and Bismuth II, the Appellate Body explicitly ruled that unsolicited amicus curiae briefs are admissible in Appellate Body proceedings: "We are of the opinion that we have the legal authority under the Dsu to accept and consider amicus curiae briefs in an appeal in which we find it pertinent and useful to do so. In this appeal, we have not found it necessary to take the two amicus curiae briefs filed into account in rendering our decision." Appellate Body Report, United States_Imposition of Countervailing Duties on Certain Hot-Rolled Lead and Bismuth Carbon Steel Products Originating in the United Kingdom, wT/Ds138/AB/R (May 10, 2000). See Arthur E. Appleton, 'Amicus Curiae Submissions in the Carbon Steel Case: Another Rabbit from the Appellate Body's Hat?' (200o) 3(4) Journal of International Economic Law 691; Denise Prévost, 'WTo Subsidies Agreement and Privatised Companies. Appellate Body Amicus Curiae Briefs' (2000) 27 Legal Issues Economic Integration 279. See also Jacqueline Peel, 'Giving the Public a Voice in the Protection of the Global Environment: Avenues for Participation by NGOs in Dispute Resolution at the European Court of Justice and the World Trade Organization' (2001) Colorado Journal of International Environmental Law \& Policy 47. 
This position was strongly attacked by trade experts, academic commentators, and Member delegates, in particular from developing countries. Regardless, the Appellate Body had entered into a dialogue with outsider constituencies, which had contributed to its "enlightened" jurisprudence.

This "enlightened" jurisprudence represents, together with the discussions within the CTE, the only concrete attempts to search for a balance between trade and environmental considerations at the wTо. The very same quest was proceeding at a faster pace in certain domestic systems - mostly industrialized countries - and was reflected in the position they brought forward in their bilateral and regional talks. In these contexts, simply giving exception clauses a more expansive interpretation did not seem like a sufficient response to the quest for balance: a gap that could instead be filled by drafting new 'greener' exceptions.

\subsection{FTA $s$ and the Introduction of 'Updated' Exceptions}

Nothing short of GATT reform is acceptable ... [We urge] Congress to ... seek fundamental reforms which will ensure the rights of GATT Contracting Parties to take trade actions consistent with the protection of the global resources and recognizing the validity of worldwide environmental treaties. ${ }^{161}$

DAVID PHILLIPS, Hearing Before the Subcommittee on Health and the Environment, 1991

David Phillips, of the Earth Island Institute, uttered these words as part of his testimony in the congressional hearings conducted by the US Subcommittee on Health and the Environment of the Committee on Energy and Commerce in 1991. Phillip's voice was not an isolated one. Over the course of the same hearings, Steven Shrybman, of the Canadian Environmental Law Association, suggested an amendment to the GATT to allow national governments to assert their "sovereign prerogative [of doing] what they believe is necessary in the public interest to protect the environment and conserve resources." 162 To this end, he even presented a written proposal containing a model for an amended Article xx, which began with the following words:

161 See GATT: Implications on Environmental Laws: Hearing Before the Subcomm. on Health and the Environment of the House Comm. on Energy and Commerce, 102d Cong., 1st Sess. 1 (1991), at 62 (Testimony of David Phillips).

162 Ibid., 95 (Testimony of Steven Shrybman), as quoted in Thomas E. Skilton, 'GATT and the Environment in Conflict: The Tuna-Dolphin Dispute and the Quest for an International Conservation Strategy' (1993) 26 Cornell International Law Journal 455, 485. 
(1) Nothing in this agreement shall be construed to prevent any party from taking any action which it may deem necessary to protect the environment, including the establishment of import or export restrictions and the use of subsidies to: (i) prevent or remedy adverse environmental effects, and/or; (ii) conserve natural resources. ${ }^{163}$

Along the same lines, and only a few years later, the European Union participated in the first round of discussions at the newly stablished CTE by proposing, among other things, the amendment of GATT Article Xx, either by including a reference to "measures taken pursuant to specific MEAs" or "in more general terms, to measures necessary to protect the environment."164

However, none of these proposed amendments were introduced in the text of the GatT. The Appellate Body's 'enlightened' jurisprudence on Article XX has proven to be the only means to address some of the concerns underlying these proposals, at least at the multilateral level. It was instead in the context of bilateral and regional trade negotiations that many of these proposals found a much more promising breeding ground.

163 The proposed Article continued: "(2) For greater certainty, "actions necessary to protect the environment" shall include national and international initiatives, including, but not restricted to: (i) the establishment of regulatory regimes including environmental standards, objectives, guidelines and codes of practice; (ii) approval processes relating to environmental impact assessment of projects or programs that may have significant environmental con- sequences, including the determination of whether approval for such projects or programs shall be granted; (iii) measures intended to encourage public participation and standing in the decision-making processes that may affect the environment, and; (iv) access to information on matters relating to the environment. (2) For the purpose of resolving or adjudicating any dispute that may arise under this agreement with respect to any action taken to protect the environment, the onus shall be upon the complainant to prove that: (i) the action or measure was not taken in good faith, and; (ii) is unreasonable."

164 CTE, Non-Paper by the European Communities on Item 1. This is just one of many similar proposals. Hurlock, for example, suggests the introduction of an additional subparagraph under GATT Article $\mathrm{xx}$ - letter ( $\mathrm{k}$ ) - related to measures adopted pursuant to multilateral environmental agreements. For the complete text of the proposed provision, see Matthew H. Hurlock, 'Note. The GatT, US Law and the Environment: A Proposal to Amend the GATT in Light of the Tuna/Dolphin Decision' (1992) 92 Columbia Law Journal 2098, 2148. Other proposals are even more drastic. Over the course of the Uruguay Round, US Senator Max Baucus, for example, had been advocating the negotiations of a GATT side-agreement that would account for environmental issues, an 'Environment Code', along the lines of the Tokyo codes on subsidies or on technical barriers to trade. See Max Baucus, 'NAFTA Needs Environmental Side Agreements' (1993) 1o Environmental Forum 30. See also Skilton, 'GATT and the Environment in Conflict' (n 162) 484 and William H. Lash III, 'Green Gang's GATt Holdup', Journal of Commerce, Dec. 10, 1993. 
At a first glance, the general exceptions contained in most free trade agreements (FTA s) seem to simply reproduce those found in wTO agreements and, in some instances, this is exactly the case. ${ }^{165}$ Other agreements, instead, formulate their own exception clauses with the goal of providing for greater policy space for environmental regulations. First, a number of FTA s do explicitly refer to the environment in their exception clauses. The EU-Colombia-Peru FTA, for instance, revisits the GATT wording to explicitly include environmental measures. ${ }^{166}$ A similar result is achieved by the US-Jordan FTA, which, in the context of trade in goods, clarifies that "[t]he Parties understand that the measures referred to in GATT 1994 Article Xx(b) include environmental measures necessary to protect human, animal or plant life or health, and that GATT 1994 Article $\mathrm{Xx}(\mathrm{g})$ applies to measures relating to conservation of living and non-living exhaustible natural resources." 167

Besides explicitly qualifying their exception clauses as 'environmental', some agreements omit the word "necessary" when reproducing GATT Article $\mathrm{xx}(\mathrm{b})$ and simply refer to measures "justified on grounds of ... the protection of health and life of humans, animals or plants," 168 thus eliminating the necessity test required by the GATT which, despite having become far more flexible than it used to be, still represents an obstacle to be overcome by the party defending a given environmental measure.

A third way in which new FTAs innovate with regards to the drafting of exception clauses is by expanding their scope of application beyond the chapter on trade in goods. As a matter of fact, article xx only applies to claims made under the GATT or, at least, under agreements with provisions that refer to GATT Article XX. ${ }^{169}$ However, the more recent environmental disputes brought

165 See e.g. Free Trade Agreement, EU-Iceland, Dec. 19, 1972, Art. 21; and Free Trade Agreement, EU-Norway, May 14, 1973, Art. 20.

166 Article 106 refers to measures "(b) necessary to protect human, animal or plant life or health, including those environmental measures necessary to this effect; [...] (g) relating to the conservation of living and non-living exhaustible natural resources, if such measures are made effective in conjunction with restrictions on domestic production or consumption."

167 Free Trade Agreement \& Economic Integration Agreement, United States-Jordan, Oct. 24, 2000, Art. 12. See also e.g. Free Trade Agreement \& Economic Integration Agreement, China-New Zealand, Apr. 7, 2008 [hereinafter China-N.Z. FTA], Art. 20o(2); Free Trade Agreement, EfTA-Canada, Jan. 26, 2008, Art. 22; Free Trade Agreement \& Economic Integration Agreement, Japan-Peru, May 31, 2011 [hereinafter Japan-Peru FTA], Art. 10; and Free Trade Agreement \& Economic Integration Agreement, Australia-China, June 17, 2015, Art. 9.8(2).

168 Free Trade Agreement, EU-South Africa, Oct. 11, 1999 [hereinafter EU-S. Afr. FTA], Art. 27.

169 See e.g. SPS Agreement, Articles 1 and 2.4. According to Article 1, Members desire "to elaborate rules for the application of the provisions of GATT 1994 which relate to the 
to the WTO rarely require the application of GATT provisions, as the challenged measures generally include local-content requirements, conditional subsidies, tax rebates, and artificial limits on inputs, also known as 'green industrial policy' measures. ${ }^{170}$ Unlike the GATT, none of the disciplines governing these trade measures - such as the Agreement on Subsidies and Countervailing Measures (ASCM) or the Anti-Dumping Agreement (ADA) - contain an environmental exception that allows for a balancing test. ${ }^{171}$ And even those agreements that do include general exceptions, such as Article XIV of the General Agreement on Trade in Service (GATS), do not always mirror the exact terms of GATT Article Xx. ${ }^{172}$

Some of the more recent FTAs address these concerns by expanding the scope of application of GATT-like exceptions to numerous chapters of the agreement, or by introducing new exception clauses in chapters that traditionally did not feature one. So, the EU-Colombia-Peru FTA, among others, expands the scope of its "trade in services" exception clause by including a subparagraph on measures "relating to the conservation of exhaustible natural resources," a category that corresponds to GATT Article $\mathrm{Xx}(\mathrm{g})$ but does not instead feature in GATS Article XIV. ${ }^{173}$ Article 21.1 of the US-Singapore FTA, instead, extends GATT Article XX to its chapters 2 through 6 (National Treatment and Market Access for Goods, Rules of Origin, Customs Procedures, Textiles, Technical Barriers to Trade). ${ }^{174}$

use of sanitary or phytosanitary measures, in particular the provisions of Article $\mathrm{xx}(\mathrm{b})$, " while Article 2.4 reads as follows: "Sanitary or phytosanitary measures which conform to the relevant provisions of this Agreement shall be presumed to be in accordance with the obligations of the Members under the provisions of GATT 1994 which relate to the use of sanitary or phytosanitary measures, in particular the provisions of Article $\mathrm{xx}(\mathrm{b})$." Agreement on Sanitary and Phytosanitary Measures, Apr. 15, 1994, Marrakesh Agreement Establishing the World Trade Organization, Annex 1A, 1867 U.N.T.S. 3 [hereinafter SPS Agreement].

170 Salzman and Wu define these disputes as "Next Generation" trade and environment conflicts, as opposed to the "Classic" trade and environment disputes that revolved around the imposition of import restrictions for environmental purposes. See Mark Wu and James Salzman, 'The Next Generation of Trade and Environment Conflicts: The Rise of Green Industrial Policy' (2014) 108(2) Northwestern University Law Review 401.

171 Ibid., 452, 454.

172 Marceau and Wyatt, 'The WTO's Efforts' (n 147) 305.

173 EU-Colom.-Peru FTA, Art. 167(c).

174 See also e.g. US-Chile FTA, Art. 23; Free Trade Agreement \& Economic Integration Agreement, Canada-EU, Oct. 30, 2016 [hereinafter CETA], Art. 28.3; Free Trade Agreement \& Economic Integration Agreement, China-Singapore, Oct. 23, 2008, Art. 105; Free Trade Agreement \& Economic Integration Agreement, Australia-Chile, July 30, 2008 [hereinafter Austl.-Chile FTA ], Art. 22.1; Free Trade Agreement \& Economic Integration Agreement, Canada-Peru, May 29, 2008, Art. 2201; Free Trade Agreement \& Economic Integration 
The applicability of Article Xx, in particular, to the Ascm has been the subject of heated debates. ${ }^{175}$ The Agreement, introduced at the conclusion of the Uruguay Round, initially contained a temporary escape clause for environmental measures-albeit narrowly drafted — which elapsed in 2000 and was never renewed by the Members. ${ }^{176}$ The recent case law regarding renewable energy subsidies ${ }^{177}$ has brought to the surface the inherent shortcomings of the existing subsidies discipline: the one-size-fits-all approach adopted by the Agreement, where all subsidies are lumped in the same basket, has been widely criticized for not allowing the distinction between undesirable subsidies and those that are adopted for legitimate reasons. ${ }^{178}$

Agreement, Costa Rica-Singapore, Apr. 6, 2010, Art 18.2; and Free Trade Agreement \& Economic Integration Agreement, Mexico-Panama, Apr. 3, 2014 [hereinafter Mex.-Pan. FTA], Art. 19.2. The agreement between Singapore and Turkey, e.g., extends the applicability of Article xx to the Chapter of Investment as well. See Free Trade Agreement \& Economic Integration Agreement, Turkey-Singapore, Nov. 14, 2015 [hereinafter Turk.Sing. FTA], Art. 12.24.

175 The 2006 World Trade Report of the wTo Secretariat, in its legal analysis, suggests: "While Article $\mathrm{XX}$ in principle would apply to subsidies, the more specific rules of the ASCM in any case are explicitly geared to remedying trade distortions arising from subsidization," 201.

176 Article 8 of the AScm, now no longer in force, allowed subsidies devoted to the "assistance to promote adaptation of existing facilities to new environmental requirements imposed by law and/or regulations which result in greater constraints and financial burden on firms" provided that some conditions were met. See e.g. Paolo D. Farah and Elena Cima, 'World Trade Organization, Renewable Energy Subsidies and the Case of Feed-in Tariffs: Time for Reform Toward Sustainable Development?' (2015) 27 Georgetown International Environmental Law Review 516.

177 Appellate Body Report, Canada - Certain Measures Affecting the Energy Generation Sector, WT/DS412AB/R (May 6, 2013) [hereinafter Canada-Renewable Energy] and CanadaMeasures Relating to the Feed-In Tariff Program wT/Ds426AB/R (May 6, 2013) [hereinafter Canada—FIT Program]. Appellate Body Report, India-Certain Measures Relating to Solar Cells and Solar Modules, WT/DS456/AB/R (Sept. 16, 2016).

178 Alan Sykes, 'The Economics of wTo Rules on Subsidies and Countervailing Measures' (2003) University of Chicago Law \& Economics, Olin Working Paper No. 186, 1. See also Steve Charnovitz and Carolyn Fischer, 'Canada-Renewable Energy: Implications for wто Law on Green and Not-So-Green Subsidies' (2015) 14(2) World Trade Review. Petros C. Mavroidis and Aaron Cosbey, 'A Turquoise Mess: Green Subsidies, Blue Industrial Policy and Renewable Energy: The Case for Redrafting the Subsidies Agreement of the WTO' (2014) EuI Working Paper RSCAS 2014/17. Moreover, because the GATT covers measures - such as total bans and quotas - which are widely known as more restrictive and trade-distorting than subsidies, the lack of an exception in the Аsсм would end up according more distorting measures a more favorable treatment. See Robert Howse, 'Climate Mitigation Subsidies and the wTo Legal Framework' (2010) IISD; Luca Rubini, 'Ain't Wastin' Time No More: Subsidies for Renewable Energy, the scm Agreement, Policy Space and Law Reform' (2012) 15 Journal of International Economic Law 525. 
Scholars have been discussing ways to fill this gap and different views have been put on the table, from reinstating the category of non-actionable subsidies - or introducing a new one-to extending the application of GATT Article XX to the ASCM. ${ }^{179}$ Once again, FTA s seem to have started addressing these concerns. Article 12.9 of the EU-Japan FTA, for instance, extends GatT Article $\mathrm{xx}$ to its chapter on subsidies, while other agreements, as the next section will explain in further detail, have introduced a different kind of environmental escape clause in their subsidies chapter, precisely to allow the distinction between undesirable subsidies and subsidies that pursue legitimate (environmental) policy goals.

\subsection{An Exception and Nothing More}

While the Appellate Body's jurisprudence of the last 30 years has provided WTO Members with greater environmental policy freedom through means of interpretation, free trade agreements, beginning with NAFTA, have allowed the environment to have a more significant presence in their text: by means of treaty interpretation and negotiation, the dialogue about trade and the environment appears to have permanently changed.

However, without detracting at all from this discernible evolution, the dominant narrative has hardly changed: the environment continues to be treated as nothing more than an exception, although a much broader one than it used to be, as "GATT Article XX remains the arbiter, balancing environmental protection against trade protectionism when conflicts arise."180 If it is true that, unlike the pre-Tuna/Dolphin and pre-wто era, it is generally acknowledged that environmental and trade goals can and should be pursued in a mutually supportive manner trying to avoid or minimize all possible conflicts, on the other hand all the efforts towards this end seem to concentrate solely on how

179 For different proposals, see Andrew Green, 'Trade Rules and Climate Change Subsidies' (2006) 5 World Trade Review 377, 408-10; Robert Howse, 'Do the World Trade Organization Disciplines on Domestic Subsidies Make Sense? The Case for Legalizing Some Subsidies', in Kyle W. Bagwell et al. (eds.), Law and Economics in Contingent Protection in International Trade 85-102 (Cambridge University Press, 2009), p. 94; Howse, 'Climate Mitigation Subsidies' (n 178) 21; Tracey Epps and Andrew Green, Reconciling Trade and Climate 256-57 (Edward Elgar, 2010); Rubini, 'Ain't Wastin' Time No More' (n 178) 570-77; Gary Horlick and Peggy Clarke, 'Rethinking Subsidy Disciplines for the Future' (2016) E15 Task Force on Rethinking International Disciplines-Policy Options Paper, ICTSD; Elena Cima, 'Caught between Trade and Climate Change. The Economic Rationale of "Green Subsidies" ', in Klaus Mathis and Bruce R. Huber (eds.), Environmental Law And Economics 379-404 (Springer, 2017), pp. 400-1; Wu and Salzman, 'The Next Generation of Trade and Environment Conflicts' (n 170) 456 .

180 Wu and Salzman, 'The Next Generation of Trade and Environment Conflicts' (n 170) 413. 
to best use the space provided by GATT exceptions. And even in the context of the more recent disputes concerning the environment, although not based on the GATT but on other WTo Agreements, the debate continues to be framed in terms of 'exceptions'. The debate on the (lack of) space provided by the ASCM provides a good example of this trend, as most proposals have been revolving around the need to either extend the application of GATt Article xx to the ASCM, or to draft a brand-new exception clause within its text.

Along the same lines, no matter how many times the Appellate Body declares that the chapeau of Article xx should be interpreted as a means to strike a balance between two equally important rights, environmental protection is hardly recognized as a right in the Што system, and framing them merely as an exception effectively prevents environmental goals from standing on equal footing with economic ones.

Accordingly, trade law continued to be used as the framework of reference through which to evaluate environmental measures: despite the recognition that countries can pursue environmental objectives, and although they now seem to have more freedom to do so, ultimately the limit is still the respect of trade norms and the preservation of the integrity and smoothness of international trade flows. The importance of this limit has been reiterated even by the Appellate Body which, in US - Gasoline, held that, although "WTO Members have a large measure of autonomy to determine their own policies on the environment ... that autonomy is circumscribed ... by the need to respect the requirements of the GATT and other covered agreements." ${ }^{\text {181 }}$

A similar message can be found in paragraph 6 of the Doha Ministerial Declaration which, despite all the enthusiasm it generated, still subordinates states' ability to enact whatever environmental protection measures they please "to the requirement that they are not applied in a manner which would constitute a means of arbitrary or unjustifiable discrimination between countries where the same conditions prevail, or a disguised restriction on

181 Appellate Body Report, US — Gasoline, 3o, quoted by the Panel in US —Shrimps, at 7.26. This message can be found loud and clear in the text of several wTo Agreements, such as the SPs Agreement, where Article 5.6 provides that "when establishing or maintaining sanitary or phytosanitary measures to achieve the appropriate level of sanitary or phytosanitary protection, Members shall ensure that such measures are not more traderestrictive than required to achieve their appropriate level of sanitary or phytosanitary protection" (emphasis added). Similarly, Article 5.4 provides that "Members should, when determining the appropriate level of sanitary or phytosanitary protection, take into account the objective of minimizing negative trade effects." 
international trade, and are otherwise in accordance with the provisions of the wTo Agreements." 182

After all, although the two communities have managed to overcome the clinical isolation that had characterized the GATT-era, the level of integration has remained relatively weak, especially at the multilateral level. Within the WTO, the rules governing the institutional ties between the CTE and international environmental organizations had been unclear and contested for several years, ${ }^{183}$ their discussions dominated by a clear hierarchy between trade and environmental rules, and observers did not participate beyond formal reporting. ${ }^{184}$ It should then be no surprise to find that the 1996 CTE report, while acknowledging "certain complementary objectives between the WTO and MEAS ... subordinates MEAs' trade-related environmental measures (TREMS) to trade obligations." 185 Because of the diverging positions of the representatives of developed and developing countries, the weak language of the 1996 Report seemed necessary to provide the foundation around which these divergent interests could converge and a consensus text could be constructed. Moreover, it has been argued that the ten-point work program of the CTE weakened its original mandate, by targeting specific environmental issues while moving away from the promotion of sustainable development and lacking direct opportunities to recommend changes to the multilateral trading system. ${ }^{186}$ Overall, the discussions within the CTE and Ministerial negotiations

182 World Trade Organization, Ministerial Declaration of 14 November 2001, WT/MIN(01)/ DEC/1, 41 I.L.M. 746 (2002) [hereinafter Doha Declaration], para. 6.

183 Observership in the wTO is regulated by the 1996 Guidelines on Observer Status for International Intergovernmental Organizations in the WTO, WT/L/161 (July 25, 1996) [hereinafter Guidelines]. Granting observer status is usually related to specific sessions or specific organs of the Organization and each request is assessed on a case-by-case basis, taking into account, among other factors, the nature of the work of the organization concerned, the nature of its membership, the number of wTо Members in the organization, and reciprocity with respect to access to proceedings.

184 As to the rights of the observers, the Guidelines specify that representatives of organizations accorded observer status, beside receiving copies of the main wTO documents and of other documents relating to the work of the subsidiary bodies which they attend as observers, have the right to speak after Members have spoken and may be able to circulate papers or make proposals if expressly invited to do so. On the other hand, the Guidelines are clear when they specify that these rights do not in any event include the right to participate in any decision-making activity.

185 Melissa Gabler, 'Norms, Institutions and Social Learning: An Explanation for Weak Policy Integration in the WTO's Committee on Trade and Environment' (2010) 10(2) Global Environmental Politics 80.

186 Rachel McCormick, 'A Qualitative Analysis of the wTo's Role on Trade and Environment Issues' (2006) 6(1) Global Environmental Politics 102, 111. The original mandate, outlined in the 1994 Ministerial Declaration on the Environment, was twofold: (i) "identify the 
reflected a style of interaction between the trade and environmental communities based on simple learning about environmental norms to satisfy trade interests. ${ }^{187}$ The same can be said for the Cте Special Sessions (CTESS), ${ }^{188}$ whose mandate indicated that the possibilities for substantial changes in the prevailing trade-centered stance would be very limited. First, with regards to the first topic to be addressed by the CTESS - the relationship between WTO rules and specific trade obligations set out in MEA s-Ministers clarified that "negotiations shall be limited in scope to the applicability of ... existing WTO rules as among Parties to the MEA in question [and that] the negotiations shall not prejudice the wTo rights of any Member that is not a Party to the MEA."189 Second, outcomes "shall be compatible with the open and non-discriminatory nature of the multilateral trading system and shall not add to, diminish or alter the balance of the rights and obligations of Members under existing Wто Agreements." 190

The very same message can be found in bilateral and regional trade agreements as well. Despite being much 'greener' than their multilateral counterparts, they have continued to subordinate the parties' freedom to protect the environment to the condition that by doing so trade is not excessively restricted. Article 104 of NAFTA, for instance, which was considered revolutionary at the time because it defined the relationship between a trade agreement and multilateral environmental treaties for the first time, ${ }^{191}$ clarifies that, in case of inconsistency between NAFTA and the specific trade obligations set

relationship between trade measures and environmental measures in order to promote sustainable development;" and (ii) "make appropriate recommendations on whether any modifications of the provisions of the multilateral trading system are required, compatible with the open, equitable and non-discriminatory nature of the system."

187 Gabler, 'Norms, Institutions and Social Learning' (n 185) 105.

188 The Committee on Trade and Environment Special Sessions (CTESS) held its very first meeting on March 22, 2002, back-to-back with the regular meeting of the CTE. See wTO CTESs, Statement by the Chairperson of the Special Session of the Committee on Trade and Environment to the Trade Negotiations Committee, TN/TE/1 (Apr. 12, 2002).

189 Doha Declaration, para. 31(i). The other topics to be covered by the CTEss are "(ii) procedures for regular information exchange between MEA Secretariats and the relevant WTO committees, and the criteria for the granting of observer status; [and] (iii) the reduction or, as appropriate, elimination of tariff and non-tariff barriers to environmental goods and services."

190 Ibid., para. 32.

191 To be entirely correct, the Havana Charter did directly address the MEA issue. Article 45 provided an exception for measures "taken in pursuance of any inter-governmental agreement which relates solely to the conservation of fisheries resources, migratory birds or wild animals." See Charnovitz, 'A Critical Guide' (n 108) 346. 
out in certain MEA s, ${ }^{192}$ the latter shall prevail to the extent of the inconsistency. However, the same provision further clarifies that "where a Party has a choice among equally effective and reasonably available means of complying with" the MEA s obligations, the Party will have to choose the alternative that is "the least inconsistent" with NAFTA. ${ }^{193}$ And the same caveat can be easily spotted after every provision that addresses environmental concerns in nearly all free trade agreements signed since then.

The reader, who has followed the story up until this point, will have observed a quite discernible evolution of the relationship between the international trade and environmental regimes towards a greater mutual supportiveness, ${ }^{194}$ as suggested in the Brundtland Report, in Rio, and in nearly every single international environmental conference or summit since then. This evolution, nevertheless, continues to follow traditional patterns: the assumption is always the possibility of conflicts between the goals of the two regimes and what has emerged is rather the willingness to solve them; the relationship between trade liberalization and environmental protection continues to be approached from a purely free trade perspective and, as a result, even when more space is given to environmental values, this space is always designated as exceptional.

Looking more closely, however, the situation seems to be gradually changing and the evolution itself appears to be taking a rather different turn. This new direction, however, cannot be detected at all levels and in all fora at the same

192 NAFTA Article 104 in particular refers to Cites, the Montreal Protocol on Substances that Deplete the Ozone Layer, and the Basel Convention on the Control of Transboundary Movements of Hazardous Wastes and Their Disposal.

193 NAFTA, Art. 104. Similar language characterizes the SPS and твт chapters of the agreement. For a more recent example, see also e.g. Article 292(3) of the agreement between the EU and Ukraine: "Nothing in this Agreement shall limit the rights of a Party to adopt or maintain measures to implement the multilateral environmental agreements to which it is a Party. Such measures shall not be applied in a manner which would constitute a means of arbitrary or unjustifiable discrimination between the Parties or a disguised restriction on trade." Free Trade Agreement \& Economic Integration Agreement, EUUkraine, June 27, 2014 [hereinafter EU-Ukr. FTA], Art. 292(3).

194 For a discussion on the principle of mutual supportiveness in the context of the relationship between international trade and environmental law and, more broadly, in the context of fragmentation of international law, see Laurence Boisson de Chazournes and Makane Moïse Mbengue, 'A “Footnote as a Principle." Mutual Supportiveness in an Era of Fragmentation', in Holger P. Hestermeyer et al. (eds.), Coexistence, Cooperation and Solidarity—Liber Amicorum Rüdiger Wolfrum —Vol. II (Martinus Nijoff Publishers, 2011). 
time, or even with the same intensity. Once again, it is those countries that are pursuing, both domestically and internationally, a 'greener' agenda that are paving the way for a brand-new chapter in the trade/environment story. A new chapter where the trade community appears more and more willing to open the front door to let the environment in and take its seat at the table, if not within the Wто, at least in the context of bilateral and regional negotiations. The EU and the US are once again on the frontline, together with other developed countries like Canada, architects of a new generation of trade agreements where the idea of 'greening trade law' acquires a whole new meaning. These agreements feature provisions that give the environment a new status within their text, far beyond what we generally define as 'exceptions'. Environmental exemptions, or carve-outs, give states an autonomous right to pursue environmental objectives and so do those provisions that recognize countries' regulatory sovereignty in the environmental realm, integrate general environmental principles, and provide for environmental obligations of a mandatory nature.

\subsection{The (Not So) Thin Line between Exceptions and Exemptions}

(1) A procuring entity shall not prepare, adopt or apply any technical specification or prescribe any conformity assessment procedure with the purpose or the effect of creating unnecessary obstacles to international trade.

(6) For greater certainty, a Party, including its procuring entities, may, in accordance with this Article, prepare, adopt or apply technical specifications to promote the conservation of natural resources or protect the environment.

Government Procurement Agreement, Revised Text, 2012, Article X

Article x of the Revised Agreement on Government Procurement (GPA) contains an environmental 'exemption' in its discipline on technical specifications. Although an 'exemption' should never be confused with an 'exception', the risk of confusion is fairly common. In fact, the term 'exception' is often usedmisleadingly — in a very broad and over-comprehensive fashion, to encompass all clauses which identify situations where trade rules do not apply or prevail in order to accommodate domestic policies. The reason why using the term 'exception' interchangeably may be misleading is that several different techniques exist to achieve such exclusion, and each of them carries different legal implications. ${ }^{195}$

195 Viñuales, for example, identifies up to seven techniques that can be employed in treaties to "escape a rule." The seven techniques identified are: i) delimitation of the scope of a 
The escape clauses discussed so far-mainly GATT Article XX-can be characterized as exceptions stricto sensu. However, over the course of the years, a different type of escape clause - referred to as 'exemption' or 'carve out'- has been gradually introduced to allow countries to pursue, among others, environmental objectives. The agreements on Technical Barriers to Trade (ТВT) and on Sanitary and Phytosanitary Measures (SPS), for instance, contain exemptions that are relevant for the environment. ${ }^{196}$ Article $\mathrm{x}$ of the Revised Agreement on Government Procurement (Revised GPA), quoted at the beginning of this section, similarly contains an environmental exemption. ${ }^{197}$ Interestingly, this provision was only added when the Agreement was amended in 2012 while, when the GPA was first drawn up during the Uruguay Round, it did not contain any reference to the environment in its provision on technical specifications. ${ }^{198}$ Between 1995 and 2012, a number of bilateral negotiations had led to the adoption of FTAs whose chapters on government procurement began introducing the very same exemption, which ultimately found its way on the table of the Revised GPA negotiators. ${ }^{199}$

Recent FTA s feature a wider variety of environmental exemptions. Many examples can be found in their investment chapters. Annex 8-A of the EUCanada Comprehensive Economic and Trade Agreement (CETA), for example, explicitly excludes from the definition of 'indirect expropriation' "nondiscriminatory regulatory actions by a Party that are designed and applied to protect legitimate public welfare objectives, such as public health, safety and the environment" except in rare circumstances. ${ }^{200}$ Similar environmental

norm or set of norms; ii) specific carve-outs or exemptions; iii) flexibilities; iv) derogations; v) exceptions stricto sensu; vi) excuses; and vii) circumstances precluding wrongfulness. Jorge E. Viñuales, 'Seven Ways of Escaping a Rule: Of Exceptions and Their Avatars in International Law', in Lorand Bartels and Federica Paddeu (eds.), Exceptions and Defences in International Law (Oxford University Press, 2020).

196 See sps Agreement, Art. 3.3 and, Agreement on Technical Barriers to Trade, Apr. 15, 1994, Marrakesh Agreement Establishing the World Trade Organization, Annex 1A, 1868 U.N.T.S. 120 [hereinafter твт Agreement], Art. 2.4.

197 Wто, Committee on Government Procurement, Decision on the Outcomes of the Negotiations under Article XXIV:7 of the Agreement on Government Procurement, GPA/113, Apr. 2, 2012 [hereinafter Revised G PA], Art. X.

198 See Agreement on Government Procurement, April 14, 1994, Marrakesh Agreement Establishing the World Trade Organization, 1869 U.N.T.s. 508 (1994) [hereinafter GPA], Art. vi.

199 See Austl.-Chile FTA, Art. 15.12(6); Can.-Colom. FTA, Art. 1407; Japan-Peru FTA, Art. 149(5). For later examples, see S. Kor.-N. Z. FTA, Art. 13.13(6); Can.-Ukr. FTA, Art. 10.10(6); CETA, Art. 19.9.6; and Free Trade Agreement \& Economic Integration Agreement, JapanAustralia, July 8, 2014, Art. 17.7(8).

200 CetA, Art. 8.12 and Annex 8-A. Other examples include US-Chile FTA, Annex 10-D, USAustl. FTA, Annex 11-B; China-N. Z. FTA, Annex 13; Turk.-Sing. FTA, Annex 12-A; Free Trade 
carve-outs can be found in other investment provisions, such as those on the prohibition of performance requirements, ${ }^{201}$ as well as in the Chapters dealing with marking and labelling, government procurement, and trade facilitation. ${ }^{202}$

The EU-Singapore FTA stands out as it provides for an exemption within its subsidies discipline, marking a stark departure from the multilateral subsidies discipline that does not even feature an exception clause. The agreement allows the two parties to provide for subsidies that do have trade effects on the other party — as long as such effects are contained and the subsidy is limited to the minimum needed to achieve the objective-when such subsidies are necessary to achieve an objective of public interest, explicitly including subsidies "for environmental purposes." 203

Agreement \& Economic Integration Agreement, United States-Morocco, June 15, 2004, Annex 10-B; Free Trade Agreement \& Economic Integration Agreement, Dominican Republic-Central America-United States, Aug. 5, 2004, Annex 10-C; Free Trade Agreement \& Economic Integration Agreement, Canada-Panama, May 14, 2010, Annex 9.11; Free Trade Agreement \& Economic Integration Agreement, Republic of Korea-Vietnam, May 5, 2015, Annex 9-B; and Free Trade Agreement \& Economic Integration Agreement, Costa Rica-Colombia, May 22, 2013, Annex 12-B. This type of carve-out has been invoked in a number of recent disputes, which clearly show the legal implications of using carve-outs rather than exceptions. See e.g. Adel A Hamadi Al Tamimi v. Sultanate of Oman, ICSID Case No. ARB $/ 11 / 33$, Award (Nov. 3, 2015) [hereinafter Al Tamimi v. Oman].

201 More precisely, the prohibition to impose or enforce the requirement to achieve a given level or percentage of domestic content, to purchase, use, or accord a preference to goods produced in its territory, or to purchase goods from persons in its territory, or to transfer a particular technology, production process, or other proprietary knowledge to a person in its territory, does not apply to measures "(ii) necessary to protect human, animal, or plant life or health; or (iii) related to the conservation of living or non-living exhaustible natural resources." See NAFTA, Art. 1106, US-Chile FTA, Art. 10.5, Mex.-Pan. FTA, Art. 10.7(7), and US-Sing FTA., Art. 15.8. See also Free Trade Agreement \& Economic Integration Agreement, United States-Peru, Apr. 12, 2006, Art. 10.9; Free Trade Agreement \& Economic Integration Agreement, Peru-Mexico, Apr. 6, 2011, Art. 11.7(2); Free Trade Agreement \& Economic Integration Agreement, Canada-Republic of Korea, Sept. 22, 2014, Art. 8.8(2).

202 According to the EU-Colom.-Peru FTA, Parties that require mandatory marking or labeling or products shall not require the approval, registration, or certification of labels or marking as a precondition for sale in their respective markets "d) unless necessary in view of the risk of the products to human, animal or plant health or life, the environment or national safety." Art. 81. See also EU-S. Kor. FTA, Art. 61(g), Free Trade Agreement \& Economic Integration Agreement, EU-Chile, Nov. 18, 2002, Art. 161.

203 EU-Sing. FTA, Art. 12.8, Annex 12-A(e). See also Annex IX of the EU-S. Afr. FTA. Another example is provided by the European Economic Area (EEA). Article 61, which regulates state aid, prohibits "any aid granted by Ec Member States, EFTA States or through State resources in any form whatsoever which distorts or threatens to distort competition by favouring certain undertakings or the production of certain goods [...] in so far as it affects trade between Contracting Parties." However, under Article 61.3(c), "aid to facilitate the 
Although sometimes articulated in very similar terms, exceptions and exemptions operate in a very different manner. Exceptions identify circumstances in which the breach of other provisions of an agreement is justified. On the other hand, exemptions do not assume the breach of any provision, as they function as a removal of a given measure from the scope of application of a rule or set of rules, with the effect that said rule (or set of rules) will not apply to the carved-out measure. ${ }^{204}$ This distinction is very important as it carries with it different legal implications, in particular with reference to the allocation of the burden of proof and interpretation. ${ }^{205}$

As to the allocation of the burden of proof, the maxim that the respondent bears the burden of proving the exception only applies to exceptions and not to exemptions. In the presence of an exemption, in fact, the burden will not be on the respondent but rather on the complainant to prove that a general rule has been violated by the respondent and that the respondent does not fall under the situation foreseen by the excluding provision. ${ }^{206}$ In $E C$ - Hormones, the

development of certain economic activities or of certain economic areas, where such aid does not adversely affect trading conditions to an extent contrary to the common interest" may be compatible with the functioning of the Agreement. See Cima, 'Caught between Trade and Climate Changeo' (n 179) 400-1.

204 The wTо Appellate Body has grasped and clarified this distinction on several occasions. In US-Shrimps, it defined Article xx of the GATT as a "limited and conditional exception from the substantive obligations contained in the other provisions of the GATT 1994" (para. 157), following the approach of earlier GATT panels. By contrast, in CanadaPeriodicals, referring to GATT Article III:8, it stated that this provision exemplifies "the kinds of programs which are exempted from the obligations of Articles III:2 and III:4." Appellate Body Report, Canada_Certain Measures Concerning Periodicals, WT/DS31/AB/ R (June 30, 1997), 33-4. In subsequent cases, it was further clarified that the measures falling under Article III:8 "do not violate Article III" and are not subject to the national treatment obligations set out therein. The distinction between the two categories of provisions was made even clearer in cases arisen under the твт and Sps Agreements. In EC-Hormones, discussing the scope of Article 3.3 of the sps Agreement, the Appellate Body reversed the panel's finding that a "general rule-exception" relationship existed between Article 3.1 and 3.3 of the SPS Agreements, to explain that there is a qualitative difference between this relationship and the one between Articles I and III and Article XX of the GATT, precisely because Article 3.1 "simply excludes from its scope of application the kinds of situations covered by Article 3.3." Appellate Body Report, European Communities-Measures Concerning Meat and Meat Products, WT/DS26/AB/R (Jan. 16, 1998) [hereinafter EC-Hormones], paras 104 and 172.

205 The distinction between different techniques is not a prerogative of trade agreements but applies to international treaties broadly. See Viñuales, 'Seven Ways of Escaping a Rule' (n 195).

206 Michelle T. Grando, Evidence, Proof, and Fact-Finding in WTo Dispute Settlement (Oxford University Press, 2009). 
Appellate Body reversed the panel's finding that the burden of proof regarding SPS Article 3.3 had to be assigned to the respondent and clarified that it was for the United States and Canada (the complainants) to prove that the excluding norm did not apply. 207

Because the panel or Appellate Body have to find against the party bearing the burden of proof when the evidence is not sufficient or the arguments are in equipoise, framing an excluding provision as an exception or an exemption can produce far-reaching effects. An element that further exacerbates the distance between the two scenarios is the standard of proof required to prove the violation of a primary norm vis-à-vis the applicability of an exception. The burden of persuasion imposed on the complainant to prove the violation of a general obligation (such as those contained in Articles I, III, and XI of the GATT), is generally rather 'light' when compared to that borne by the respondent, ${ }^{208}$ leading some scholars to argue that it is precisely the 'light' burden imposed on the complainant to have contributed towards some (type II) errors, where a measure that should have been allowed is found inconsistent instead. ${ }^{209}$

Another element that makes exemptions more advantageous for the respondent in an hypothetical trade/environment dispute is the way in which these provisions are interpreted by the adjudicating bodies. The traditional approach in international practice has been to give primary norms an expansive interpretation, leading to a broad range of measures falling under their scope, and to interpret exception clauses restrictively.

207 Appellate Body Report, EC — Hormones paras 107-9. This statement formed the basis of Appellate Body decisions in later твт cases, such as EC-Sardines, where the Appellate Body stressed that "it [was] for Peru—as the complaining Member seeking a ruling on the inconsistency with Article 2.4 of the твт Agreement of the measure applied by the European Communities - to bear the burden of proving its claim," as the second part of твт Article 2.4 represents an exemption and not an exception. Appellate Body Report, European Communities —Trade Description of Sardines, WT/DS231/AB/R (Sept. 26, 2002), paras. 275 and 282 .

208 For example, with regard to both Article III and XI of the GATT, no adverse effects need to be shown to establish a violation. If we break down these provisions into their various components, we reach similar conclusions. With regard to Article III, for example, when determining whether a product has been taxed "in excess," even a minimal tax differential is sufficient. See Appellate Body Report, Japan-Alcoholic Beverages II, at. 23. See also Henrik Horn and Petros C. Mavroidis, 'Burden of Proof in Environmental Disputes in the wто: Legal Aspects' (2009) Research Institute for Industrial Economics, IFN Working Paper No. 793, 14.

209 Based on the distinction between Type I errors, where a truly guilty defendant escapes liability, and Type II errors, where a truly innocent defendant is found liable. Horn and Mavroidis, 'Burden of Proof' (n 208) 41. 
It is true that recent Appellate Body reports seem to have re-interpreted the principle of strict interpretation to deny that it constitutes a mandatory principle to be followed by adjudicative bodies. In EC-Hormones, the Appellate Body stated that

... merely characterizing a treaty provision as an 'exception' does not by itself justify a 'stricter' or 'narrower' interpretation of that provision than would be warranted by examination of the ordinary meaning of the actual treaty words, viewed in context and in the light of the treaty's object and purpose, or, in other words, by applying the normal rules of treaty interpretation. ${ }^{210}$

However, as it has been suggested, with this statement the Appellate Body has simply clarified that qualifying a provision as an exception does not automatically trigger a strict interpretation, not that exceptions should not be interpreted restrictively. ${ }^{211}$ Moreover, the Appellate Body has often emphasized that exceptions operate in a limited and conditional way. In US - Shrimps, for instance, it stressed the "limited ambit of such exceptions because the lack of their determinacy could otherwise endanger the integrity of the primary obligations under the relevant treaty."212 The chapeau of Article Xx, in addition, puts further limitations on the operability of the exceptions under GATT Article Xx. ${ }^{213}$

Exemptions have not been addressed as thoroughly as exceptions with respect to their interpretation. If one were to follow the principle according to which "the more exceptional the clause the more restrictive the interpretation," as explained by Viñuales, being exemptions less exceptional than

210 Appellate Body Report, EC-Hormones, para. 104.

211 Asif H. Qureshi, Interpreting WTO Agreements. Problems and Perspectives (Cambridge University Press, 2006), p. 109. Similarly, referring to general rules of treaty interpretation does not change much in practice, as the principle exceptio est strictissimae applicationis "is not independent of this treaty material but rather draws from it." Ibid., p. 110.

212 Appellate Body Report, US - Shrimps, para. 157.

213 As to the principle of effective interpretation, it refers only to the right to invoke exceptions, which should not be rendered illusory by an overly restrictive interpretation thereof. As the Appellate Body clarified in US-Gasoline, if the exceptions in GATT Article xx should not "be read so expansively as seriously subvert the purpose and object of Article III:4, .... Article III:4 [should not] be given so broad a reach as effectively to emasculate Article $\mathrm{xx}(\mathrm{g})$ and the policies and interests it embodies." By contrary, this principle should not "enable exception clauses to exceed their profile as exceptions and encroach on what is regulated under the 'primary provisions' under the treaty." Appellate Body Report, US - Gasoline, 18. See Alexander Orakhelashvili, The Interpretation of Acts and Rules in Public International Law (Oxford University Press, 2008), p. 428. 
exceptions, it would follow that their interpretation should be less restrictive. ${ }^{214}$ The investment dispute Mesa $v$. Canada provides a quite clear example of such an approach. ${ }^{215}$ The claimant (Mesa) suggested that NAFTA "Article $1108(7)$ (a) must be interpreted restrictively because it is an exception,"216 while the tribunal qualified the provision as a carve-out, whose function is "to exclude all procurement activities from the scope of some of the obligations of Chapter 11,"217 and sided with the Appellate Body in Canada-Renewables in interpreting the term 'procurement' broadly. ${ }^{218}$

The importance of the use of exemptions in the context of the trade/environment debate is not limited to the legal implications studied in this section. The introduction of these clauses marks a departure from the traditional way in which the nexus has been approached, in that they identify a country's autonomous right to pursue environmental objectives, rather than simply an exception from a general treaty obligation, as clearly explained by the Appellate Body in EC-Hormones: "The right of a Member to determine its own appropriate level of sanitary protection is an important right ... this right ... is an autonomous right and not an 'exception' from a 'general obligation."219 The same result is achieved with those provisions, increasingly featured in FTA s, which recognize countries' regulatory 'environmental' sovereignty.

\section{The Right to Protect the Environment}

... relating to the level of protection, we note that it is undisputed that Wто Members have the right to determine the level of protection of health that they consider appropriate in a given situation.

Appellate Body Report, EC-Asbestos, para. 168

In 1997, France introduced a ban on asbestos and on products containing asbestos fibers. ${ }^{220}$ Asbestos had been long known to be a deadly carcinogen and France was determined to eradicate this serious health hazard once and for

\footnotetext{
214 Viñuales, 'Seven Ways of Escaping a Rule' (n 195).

215 Mesa Power Group, LLC v. Government of Canada, UnCitral, PCA Case No. 2012-17 [hereinafter Mesa v. Canada]. See Viñuales, Seven Ways of Escaping a Rule' (n 195).

216 Mesa v. Canada, para 405 .

217 Ibid., para 427.

218 Ibid., paras 411-413. Appellate Body Report, Canada - FIT Program, para 5.59, where the Appellate Body understood 'the word 'procurement' to refer to the process pursuant to which a government acquires products.” Viñuales, 'Seven Ways of Escaping a Rule' (n 195).

219 Appellate Body Report, EC - Hormones, para. 172.

220 Décret no. 96-1133 relatif à l'interdiction de l'amiante, pris en application du code de travail et du code de la consummation (Jan. 1, 1997).
} 
all. Even though the ban applied to both domestically produced and imported asbestos, Canada argued that the kind of asbestos it exported (chrysotile) did not present any health risks when used in a safe manner and should therefore be allowed into the French market. ${ }^{221}$

Both the panel and the Appellate Body, when addressing the applicability of GatT Article $\mathrm{xx}(\mathrm{b})$ to the French ban, started from the assumption that countries could set their own level of protection, and concluded that the analysis of the 'necessity' of the ban had to be based on the specific level chosen by France. That the choice of the level of protection deemed appropriate is a prerogative of the member concerned rather than the panel or Appellate Body had already been established in Australia-Salmon: "We do not believe that Article 11 of the DSU ... entitles the Panel or Appellate Body ... to substitute its own reasoning about the implied level of protection for that expressed consistently by Australia."222 It follows that each member can choose the level of risk they are willing to endure and, in both cases, France and Australia chose the risk to be equal to zero-so-called 'zero risk.' ${ }^{223}$ France, in particular, was determined to halt the spread of asbestos-related health risks, and that is precisely why such a trade-restrictive measure - a total import ban - was chosen. Despite Canada's attempts to argue, in appeal, that 'controlled use' could represent a reasonably available alternative that would serve the same end, ${ }^{224}$ the Appellate Body was firm in ruling that "such an alternative measure would, in effect, prevent France from achieving its chosen level of health protection" and therefore deemed the French ban to be necessary. ${ }^{225}$

Although these disputes deal with public health, wто Members enjoy the same 'regulatory sovereignty' in the context of environmental protection. Under wTo law, however, the right to define one's own level of protection is not an "absolute or unqualified right." 226 Even though countries are free to choose

221 Appellate Body Report, EC-Asbestos, para. 16.

222 Appellate Body Report, Australia-Measures Affecting Importation of Salmon, WT/DS18/ AB/R (Oct. 20, 1998) [hereinafter Australia-Salmon], para. 199. See also Appellate Body Report, US — Gasoline, at 30 and Appellate Body Report, EC — Hormones, para. 172: "The rights of a Member to determine its own appropriate level of sanitary protection is an important right ... made clear by the sixth preambular paragraph of the SPS Agreement: 'Desiring to further the use of harmonized sanitary and phytosanitary standards ... without requiring Members to change their appropriate level of protection of human, animal, or plant life or health'." See also Appellate Body Report, Brazil—Tyres, para. 140.

223 Appellate Body Report, Australia-Salmon, para. 124-5; Appellate Body Report, ECAsbestos, para. 168.

224 Appellate Body Report, EC — Asbestos, para. 173.

225 Ibid., para. 174.

226 Appellate Body Report, EC—Hormones, para. 173. 
the level of protection they deem appropriate, they are generally required to use international standards. ${ }^{227}$ The underlying rationale is to achieve a certain harmonization of domestic environmental standards, as diverging standards are still seen as barriers to smooth trade flows. The SPS and твт Agreements allow Members to exceed the protection of such international standards but only provided that certain conditions are met. ${ }^{228}$

Once again, free trade agreements take it one step further. NAFTA, in its Chapters 7 and 9, removes these conditions simply stating that:

Nothing in paragraph 1 shall be construed to prevent a Party, in pursuing its legitimate objectives, from adopting, maintaining or applying any standards-related measure that results in a higher level of protection than would be achieved if the measure were based on the relevant international standard. ${ }^{229}$

As a result, the agreement manages to favor harmonization while at the same time preserving the parties' right to choose higher levels of protection and ensuring that such harmonization does not occur in a downward fashion, ${ }^{230}$ introducing a provision that has become an essential component of the environmental chapter of many modern FTA s.

Moreover, the new generation of free trade agreements has been taking this trend to the next level. Many explicitly recognize the parties' right to determine the level of environmental protection they deem suitable considering their national priorities, and the sovereignty over the enforcement of environmental measures. ${ }^{231}$ They have also started including provisions that are slowly shaping them into instruments that can be actively used to pursue environmental objectives.

227 SPs Agreement, Art. 3.1, and твт Agreement, Art. 2.4.

228 See SPS Agreement, Arts. 3.3 and 5.

229 NAFTA, Art. 905.3. The exact same wording can be found in Article 713.3.

230 See Housman, 'The North American Free Trade Agreement's Lessons' (n 8) 405.

231 See all FTAs signed by the US after NAFTA, as well as the following agreements: EU-S. Kor. FTA, Art. 13.3; EU-Colom.-Peru FTA, Art. 268; EU-Ukr. FTA, Art. 29o; EU-Sing. FTA, Art, 13.2; EU-SADC, Art. 9.1; CETA, Art. 24.3; EU-Japan, Art. 16.2; Free Trade Agreement \& Economic Integration Agreement, EU-Caribbean Forum, Oct 15, 2008, Art. 184.1; Free Trade Agreement \& Economic Integration Agreement, EU-Georgia, June 27, 2014, Art. 228; and Free Trade Agreement \& Economic Integration Agreement, EU-Moldova, June 27, 2014, Art. 364. See also e.g. Agreement on Environmental Cooperation, Canada-Chile, Feb. 1997, Art. 3; and Free Trade Agreement \& Economic Integration Agreement, EFTAPhilippines, Apr. 28, 2016, Arts. 11.3 and 11.4. 


\subsection{FTA s' Environmental Framework}

In 1994, in his seminal book Greening the GATT, Daniel Esty called for the creation of a Global Environmental Organization (GEO) to act as counterbalance to the then soon-to-be-established wTO. ${ }^{232}$ The features of the GEO would have included: i) the definition of general environmental principles; ii) the development of a "cohesive set of norms, rules, methodologies and procedures" for countries to follow in their efforts to protect the environment, as well as baseline environmental obligations; iii) the creation of a forum for settling environmental disputes; and iv) of a focal point to facilitate the exchange of information and data, as well as the transfer of clean technologies, to gather data on environmental trends, refine analytical tools, and develop environmental indicators. ${ }^{233}$

All these features were seen as necessary to ensure that "environmental values [were] not overwhelmed by more established interests, such as trade liberalization." ${ }^{234}$ After almost 30 years, there is no sign of a Global Environmental Organization. What is there, instead, is a new generation of FTA s, which seem to be slowly moving in this precise direction: unlike in the GATT/WTO system, which only reflects the classical free trade principles (such as nondiscrimination) and only contains obligations related to trade liberalization and the elimination of protectionist behaviors, ${ }^{235}$ these new FTA s create a framework that increasingly resembles that of the GEO envisioned by Esty. Figure 1 offers a visual representation of the aforementioned framework.

\subsubsection{Environmental Principles}

Besides the recognition of the parties' right to pursue environmental objectives, all the main environmental principles have found their way in the intricate jungle of trade rules that dominate these agreements. These are the principles that, after making their first appearance in the Declaration signed in Stockholm in 1972, were further developed 20 years later in Rio and, in many cases, have acquired the status of norms of customary international law. ${ }^{236}$

\footnotetext{
232 See e.g., Daniel C. Esty, 'The Case for a Global Environmental Organization', in Peter B. Kenen (ed.), Managing the World Economy: Fifty Years after Bretton Woods (Institute for International Economics, 1994), p. 287; Steve Charnovitz, 'A World Environmental Organization' (2002) 27 Columbia Journal of Environmental Law 323; Frank Bermann, A World Environmental Organization. Solution or Threat for Effective International Environmental Governance (Routledge, 2005).

233 Esty, Greening the GATT (n 89) 82.

234 Ibid., p. 79 .

235 See the language of GATT Articles II and XI, among many others.

236 For an analysis of the Rio principles, see Jorge E. Viñuales (ed.), The Rio Declaration on Environment and Development: A Commentary (Oxford University Press, 2015); Kovar,
} 


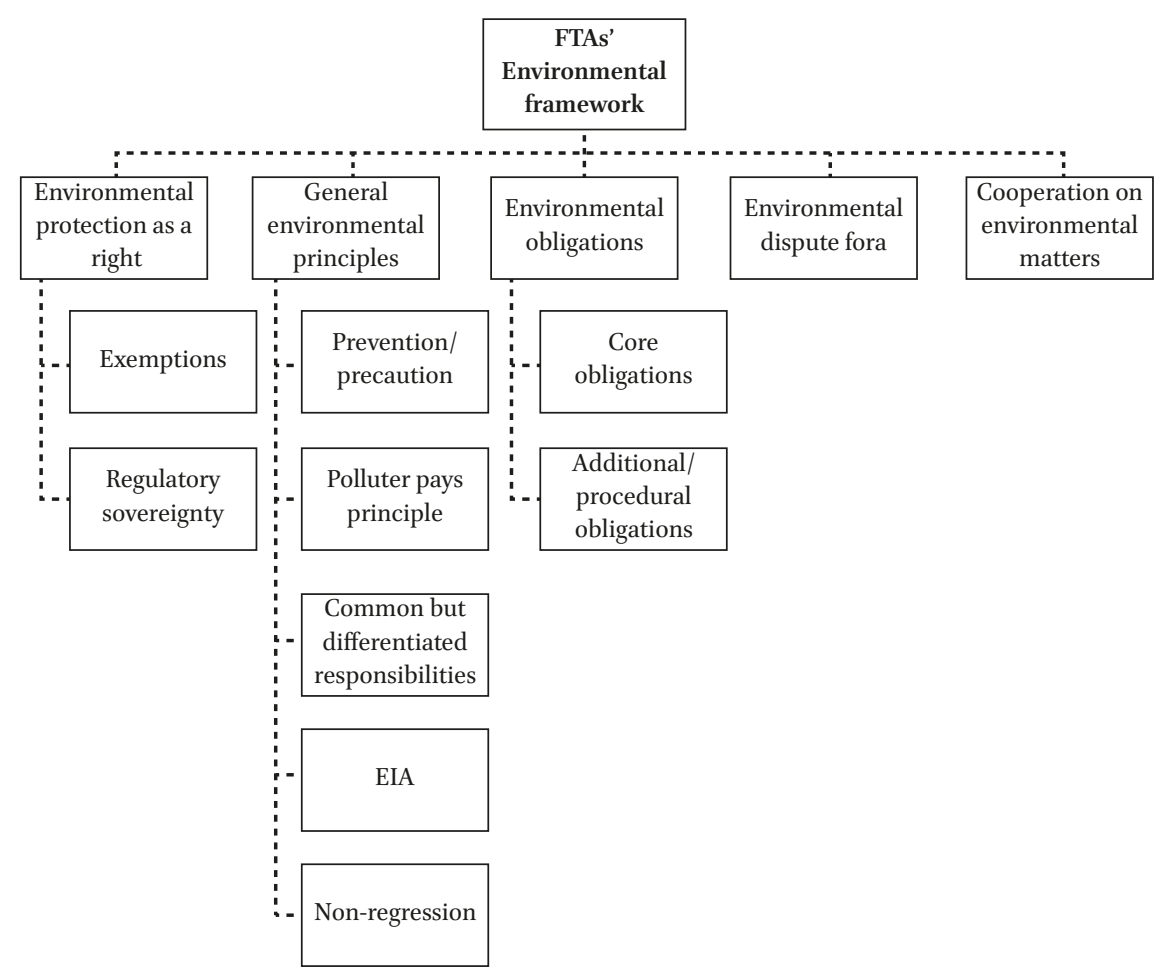

FIGURE 1 Environmental 'Framework' within trade agreements

The EU, Colombia, and Peru, for instance, have agreed to "address global environmental challenges in accordance with the principle of common but differentiated responsibilities," ${ }^{237}$ while the parties to the European Economic Area (EEA) have committed to base any action related to the environment "on the principles that preventive action should be taken, that environmental damage should as a priority be rectified at the source, and that the polluter should pay."238 Another environmental principle that has found its way in modern

'A Short Guide' (n 27) 119. See e.g. Jonathan Vessey, 'The Principle of Prevention in International Law' (1998) 3 Austrian Review of International and European law 181; John H. Knox, 'The Myth and Reality of Transboundary Environmental Impact Assessment' (2002) 96(2) American Journal of International Law 291; Philippe Cullet, Differential Treatment in International Environmental Law (Ashgate, 2003); Priscilla Schwartz, 'Polluter Pays Principle', in Malgosia Fitzmaurice et al. (eds.), Research Handbook on International Environmental Law (Edward Elgar, 2010), p. 243.

237 EU-Colom.-Peru FTA, Art. 267(4).

238 EEA, Art. 73.2. 
FTA s is the principle of non-regression. The idea of non-regression is old in international environmental law. ${ }^{239}$ It can already be found in Principle 1 of the Stockholm Declaration, which recognizes man's responsibility "to protect and improve the environment for present and future generations," so as to avoid regressing in relation to existing levels of environmental protection. ${ }^{240}$ The introduction of the principle of non-regression in the text of recent FTA s, motivated by the desire to mitigate the possibility to fail to enact or enforce environmental laws as a source of competitive advantage, has been translated in actual obligations for the states party to the agreement. ${ }^{241}$

\subsubsection{Environmental Obligations}

Next to the classical free-trade obligations - prohibition to discriminate or to impose quantitative restrictions - many FTA s feature environmental obligations which, unlike their trade counterparts, are not merely negative obligations but also include affirmative duties. The core obligations, which constitute part of the 'Pollution Haven Package' examined earlier, require the parties to enforce their environmental laws and prohibit them from lowering their level of environmental protection to attract trade or investment, thus translating the principle of non-regression examined above. Around these core commitments, FTA s generally specify additional, and often procedural, obligations. According to CETA, the parties are required to "take into account relevant scientific and technical information ... when preparing and implementing measures aimed at environmental protection that may affect trade or investment between the Parties."242 Moreover, they have committed to ensure public awareness of the respective environmental laws and enforcement compliance procedures, and to promote public participation-by encouraging public debates and submissions - with respect to the development and definition

239 Michel Prieur, 'Le principe de non régression en droit de l' environnement, condition du développement durable' (2013) Revue Africaine de Droit de l'Environnement 17.

240 United Nations Conference on the Human Environment, Stockholm, Sweden, June 5-16, 1972, Stockholm Declaration on the Human Environment, U.N. Doc. A/CONF.48/14/Rev.1, Principle 1. This principle can also be found in a wide variety of multilateral environmental agreements, such as inter alia the Paris Agreement on climate change.

241 Elena Cima and Makane M. Mbengue, 'ESIL Reflection- "Kind of Green". The U.S. Proposal to Advance Sustainability through Trade Rules and the Future of the wTo' (2021) 1O(1) ESIL Reflections. With reference to investment agreements, see Andrew D. Mitchell and James Munro, 'No Retreat: An Emerging Principle of Non-regression From Environmental Protections In International Investment Law' (2019) 5o Georgetown Journal of International Law 626, 649 .

242 CETA, Art. 24.8. 
TABLE 1 Environmental obligations in FTA S

\section{Core obligations}

Not lowering of levels of environmental protection

Enforcement of environmental laws

\section{Additional obligations}

Scientific knowledge

Public awareness and participation

Scientific knowledge when designing environmental measures

Scientific knowledge when conducting environmental risk assessment

Publication of environmental laws and regulations

Public participation in the development of environmental laws and policies

Public participation in environmental impact assessment

Environmental impact Monitor the state of the environment Conduct and review environmental impact assessments Exchange information on assessment methodologies

Invest in environmental research and science

of new environmental laws and policies. ${ }^{243}$ Similarly, parties often commit to monitor, assess, and review the environmental impact of the implementation of the agreement, as in the FTA between the EU and Singapore. ${ }^{244}$ Table 1 offers an overview of these obligations, as included in the FTA s examined.

\subsubsection{Dispute Settlement}

Any violation of these environmental obligations by one of the parties to the FTA can be challenged by the other party(ies), just like any other obligation contained in the agreement. Most agreements, such as those signed by the EU-or by the US before 2007-establish a special dispute settlement

\footnotetext{
243 Ibid., Art. 24.7.

244 EU-Sing. FTA, Art. 13.14.
} 
mechanism under their 'Sustainable Development' or 'Environment' chapters, which is able to settle any claims raised under the provisions contained therein. ${ }^{245}$

Although, in the vast majority of cases, these chapters are not covered by the general dispute settlement mechanism, the mere existence of environmental provisions or chapters within these agreements may have quite far-reaching consequences in the way trade/environment disputes are handled and ultimately decided. While trade provisions as such have not been invoked yet, and no relevant case law exists, ${ }^{246}$ an increasing number of disputes brought under the investment chapter of FTAs shows an environmental component ${ }^{247}$ and can provide us with an insight into the role that all these environmental norms can play in disputes involving FTA s. A particularly good example is provided by the interpretation of the minimum standard of treatment by the tribunal in Al Tamimi v. Oman, an investment dispute raised under the US-Oman FTA. ${ }^{248}$ The dispute, which arose with respect to the enforcement of environmental laws against a limestone quarry project, required the definition by the arbitral tribunal of the exact content of the minimum standard of treatment, as set out in Article 10.5 of the FTA. ${ }^{249}$

If the preamble to the WTO Agreement has been used by the panels and the Appellate Body to "add color, texture, and shading" to the interpretation of WTO rules, the existence of an entire chapter dedicated to the 'environment'

245 Similarly, the "investment" chapter is generally excluded from the operation of the dispute settlement mechanism established by the FTA, as it requires the parties to settle their disputes through the traditional methods of investor-state arbitration.

246 The lack of disputes under the dispute settlement mechanisms established by FTAs can sometimes be explained with the decision of the complainant to bring the dispute at the wTO. This can happen in any case of overlapping jurisdiction, which may occur whenever trade disputes arise between the Parties to an FTA, who are also wTo Members regarding obligations that are the same or similar to those of a covered agreement. See Gabrielle Marceau, 'The Primacy of the wTo Dispute Settlement System' (2015) Questions of International Law (2015).

247 See Jorge E. Viñuales, 'Foreign Investment and the Environment in International Law: The Current State of Play', in Kate Miles (ed.), Research Handbook on Environment and Investment Law (Edward Elgar, 2019).

248 Ibid. Al Tamimi v. Oman.

249 According to Article 10.5: "1. Each Party shall accord to covered investments treatment in accordance with customary international law, including fair and equitable treatment and full protection and security [and] 2. For greater certainty, paragraph 1 prescribes the customary international law minimum standard of treatment of aliens as the minimum standard of treatment to be afforded to covered investments." Free Trade Agreement \& Economic Integration Agreement, United States-Oman, Jan. 19, 2016 [hereinafter USOman FTA], Art. 10.5. 
in the the US-Oman FTA, featuring mandatory obligations for the parties to comply with, can have an even greater impact on the way in which any other norm of the agreement is interpreted. In this specific instance, the tribunal referred to both Article 10.10 and Chapter 17 of the agreement in interpreting the minimum standard of treatment.

Article 10.10 is an environmental provision within the investment chapter of the US-Oman FTA, which provides for the protection of the right of both parties to adopt, maintain, and enforce any measure to ensure that "investment activity in [their] territory is undertaken in a manner sensitive to environmental concerns." ${ }^{250}$ As part of the investment chapter, Article 10.10 falls under the jurisdiction of the tribunal, who relied upon it to construe Article 10.5. ${ }^{251}$ Chapter 17, entitled 'Environment,' on the other hand, does not fall directly within the tribunal's jurisdiction. Nevertheless, the tribunal gave substantial weight to this chapter in interpreting the content of the minimum standard of treatment, as it "provides further relevant context in which the provisions of Chapter 10 must be interpreted." 252 In the exact words of the tribunal,

... the very existence of Chapter 17 exemplifies the importance attached by the US and Oman to the enforcement of their respective environmental laws ... When it comes to determining any breach of the minimum standard of treatment under Article 10.5, the Tribunal must be guided by the forceful defense of environmental regulation and protection provided in the express language of the Treaty. ${ }^{253}$

This interpretation of the minimum standard of treatment offers a meaningful example of the way in which environmental provisions are applied and used in the context of FTA s. Unlike wTо panels and Appellate Body, panels established under an FTA will not be constrained in their mandate by an underlying purely economic rationale when performing their function. It follows that, in case of disputes administered under an FTA, free trade principles and obligations on

250 US-Oman FTA, Art. 10.10.

251 Al Tamimiv. Oman, para. 387.

252 Ibid., para. 388.

253 Ibid., para. 389. This reasoning is perfectly in line with Article 10.21 of the US-Oman FTA, entitled "Governing Law," which states in the relevant part that "the tribunal shall decide the issues in dispute in accordance with this Agreement and applicable rules of international law." Thus, while the tribunal's jurisdiction is limited to the provisions within Chapter 10, it must read them in the context and purpose of the Agreement as a whole. 
the one hand, and environmental principles and obligations on the other, will have to be balanced against one another in each individual dispute.

\subsection{The Road Ahead}

The final declaration adopted by the Singapore Ministerial Conference on December 7, 1996 stated that "the full implementation of the wTо Agreements will make an important contribution to achieving the objectives of sustainable development." ${ }^{254}$ As indicated in the Preamble to the Marrakesh Agreement, sustainable development does indeed represent one of the objectives of the Organization. The story of the evolution of the trade/environment debate as told so far, however, paints a different picture. The developments described in this chapter, although significant, have not been aimed at protecting the environment through trade norms, but rather at ensuring that trade rules would interfere less than before with countries' domestic environmental policy goals, provided, of course, that these rules are nevertheless respected. In other words, the space devoted to the environment within international trade law has been increasing but has remained 'exceptional'.

The new generation of FTA s described in the final section of this chapteralthough limited to a small number of countries-presents certain features that can no longer be explained exclusively with the prevailing narrative. The environment has become more than simply an exception, it has also become a rule. At the same time, however, the underlying rationale of these new provisions is the same as that of the expansive reading of GATT Article Xx offered by the Appellate Body in the last two decades: to allow for a fairer balance of economic and environmental goals, in order to facilitate their mutual supportiveness and reduce conflicts to a minimum. Moreover, even when the parties agree to protect the environment - for instance, by liberalizing trade in environmental goods and services - the language used in nearly all agreements is hortatory rather than providing enforceable binding obligations.

The story told so far reflects the dominant narrative generally used to describe it. This narrative is oblivious to the origin and historical evolution of the trade and environmental regimes, painting their relationship in conflictual terms. Over time, we have witnessed, as these chapters have demonstrated, changes in the composition and interactions of the respective communities, which have allowed the inherent synergy between the two regimes to gradually reach the surface. What the next chapter of this book will depict is an even more radical transformation, where trade norms are seen as instrumental to

254 Shoenbaum, 'International Trade and Protection of the Environment' (n 109) 270. 
environmental protection, showing this synergy, which had remained buried under layers of reciprocal suspicion, misconception, and, more often than not, simple unawareness for a long time. Just like trade rules were initially drafted in Havana with the ultimate goal of maintaining long-awaited peace, they can now work towards the protection of our common environment and the fulfillment of sustainable development goals. 